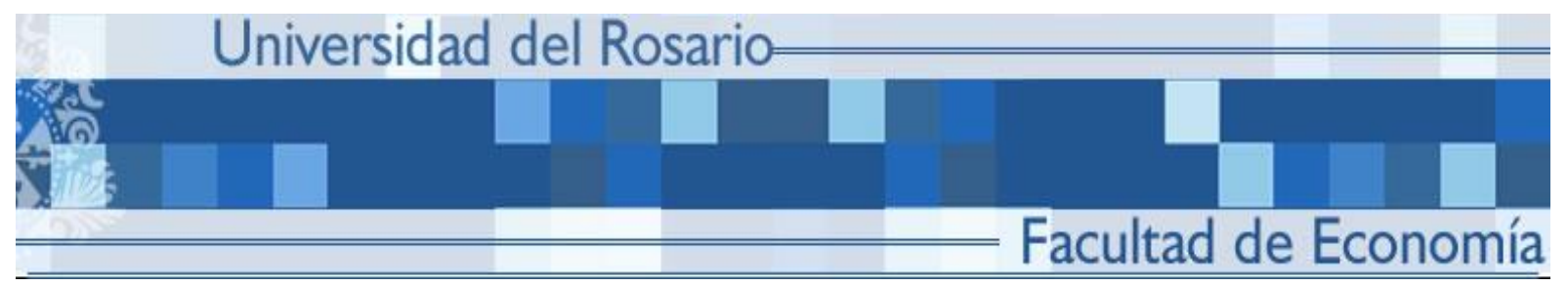

Natural Disasters and Clientelism: the Case of Floods and Landslides in Colombia*

Jorge Gallego

SERIE DOCUMENTOS DE TRABAJO

No. 178

Febrero de 2015 


\title{
Natural Disasters and Clientelism: the Case of Floods and Landslides in Colombia*
}

\author{
Jorge Gallego ${ }^{\dagger}$
}

February 10, 2015

\begin{abstract}
What are the effects of natural disasters on electoral results? Some authors claim that catastrophes have a negative effect on the survival of leaders in a democracy because voters have a propensity to punish politicians for not preventing or poorly handling a crisis. In contrast, this paper finds that these events might be beneficial for leaders. Disasters are linked to leader survival through clientelism: they generate an in-flow of resources in the form of aid, which increase money for buying votes. Analyzing the rainy season of 2010-2011 in Colombia, considered its worst disaster in history, I use a difference-in-differences strategy to show that in the local election incumbent parties benefited from the disaster. The result is robust to different specifications and alternative explanations. Moreover, places receiving more aid and those with judicial evidence of vote-buying irregularities, are more likely to reelect the incumbent, supporting the mechanism proposed by this paper.
\end{abstract}

*I would like to thank Oeindrila Dube, Rebecca Morton, Adam Przeworski and Alastair Smith for helpful comments. Maria Paula Contreras, Diego Eslava, and Gabriel Angarita provided superb research assistance. The usual caveat applies.

${ }^{\dagger}$ Facultad de Economía, Universidad del Rosario. jorge.gallego@urosario.edu.co 


\section{Introduction}

What are the effects of natural disasters on the survival of a leader? On the one hand, some authors purport that the occurrence of natural disasters has negative effects on political survival in a democracy, as voters punish incumbents even if the events are considered "acts of God" (Achen and Bartels (2004), Quiroz and Smith (2010)). On the other hand, this paper finds that natural disasters might be beneficial from an electoral perspective for democratic leaders in developing countries. The mechanism proposed links disasters to leader survival through clientelism: disasters generate an inflow of resources in the form of donations and humanitarian aid, which increase cash and resources available for buying votes. Hence, disasters might increase subsequent vote shares and the probability of reelection for those holding office, if the institutional setting in which the disaster takes place favors patronage and vote-buying.

Why is it that disasters might be beneficial for incumbents? There are at least three reasons why this may be true. First, if politicians in office are efficient at ameliorating the pervasive consequences of the disaster, an adequate provision of humanitarian assistance and relief might lead voters to reward this efficiency. Second, disasters are traumatic events that can alter political preferences and the behavior of those who have been exposed to it (Fair et al. (2014)). For instance, a disaster might increase the levels of political engagement of the affected population, and if these citizens support the incumbent, a subsequent improvement of his performance is expected. And third, incumbents might use aid and relief to buy votes. After the disaster, victims are expected to increase the propensity to sell their votes. An increased budget for buying votes and a higher propensity to sell them will result in more clientelism in favor of the incumbent. Within this paper, evidence is presented supporting the third argument, while refuting the other two.

To support these claims, the paper offers the fact that between 2010 and 2011 Colombia suffered the worst rainy season of its history, while some weeks later - in October of 2011 - local elections were held. More than 3 million people (about $8 \%$ of the Colombian population) were affected by the disaster and around 3.5 billion dollars had been allocated to ameliorate its consequences. Naturally, some municipalities were more affected than others and some have received more resources from the central government, which creates a source of variation in terms of levels of victimization and distribution of disaster relief. Consequently, the empirical strategy proposed in this paper utilizes a difference-in-differences (DID) estimator to calculate the causal effect of exposure to the disaster on the probability of reelection of the incumbent party. The paper also estimates the effect of food and 
infrastructure aid on this probability.

In the simplest specification, municipalities' level of exposure to the disaster is represented by the number of victims per capita caused by floods and landslides. Other specifications include a measure of extreme rainfall quantified by the maximum level of precipitation in 24 hours during the six months in which the rainy season was more intense. The strategy compares incumbents' probability of reelection in the 2007 (before the disaster) and the 2011 (after the disaster) mayoral races as a function of exposure to the disaster. Under a common trend assumption, the DID estimator provides a causal estimation of the effect of the disaster on incumbents' electoral performance and political survival.

In order to account for potential endogeneity concerns - given that the number of victims or the amount of aid received by a municipality are not completely exogenous to the political process or to municipality-level unobservable variables - this paper employs an instrumental variables approach to identify the causal effect of the disaster on electoral outcomes. Water supply per capita at the municipality level, which is a measure of surface runoff (or the average volume of water contained by major water bodies) is utilized as an instrument for levels of victimization. The basic argument is that municipalities surrounded by voluminous water bodies (major rivers, lakes, ponds, etc.) are more likely to experience floods during days of heavy rainfall and consequently are predicted to have a higher number of victims.

The results illustrate that, in 2011, incumbent parties had a higher probability of being reelected in mayoral elections in municipalities heavily affected by the disaster, than they did formerly in the 2007 elections. The estimations of the simplest specification suggest that, compared to a situation with no victims, a municipality in which the whole population was affected experienced an increase in the probability of reelecting the incumbent party 23 percentage points higher in 2011 . The impact is even higher when the instrumental variables approach is utilized. Furthermore, the probability of reelection is higher in municipalities that received larger amounts of humanitarian aid. In a context of climate change and global warming, these results represent a contribution to the understanding of how extreme climatic conditions and natural disasters shape political behavior and electoral outcomes.

These results are robust to several specifications and falsification tests. A potential concern of the identification strategy is that heavy rain, floods, and landslides might affect agricultural production. Income shocks generated by these events would have an impact on political preferences, altering the electoral performance of incumbents. To rule out this alternative channel, total harvested land 
per capita is controlled for at the municipality level. The production of five main agricultural products in Colombia are also controlled for within the analysis. In every case, whether the basic DID specification is used or the IV approach instead, the effect of the disaster on the probability of reelection remains positive and significant. These results suggest that even if the disaster affects agricultural production and generates income shocks, a positive and alternative effect on political survival still persists.

Additionally, I conducted a placebo test that strengthened the causal argument posed by this paper. A second rainy season took place after the October of 2011 election, which was less devastating than the first one, but still caused substantial damage and left in its wake a significant number of victims. Using the rate of victimization associated with this post-election event, it is shown that there is no relationship between this disaster and electoral performance. The second rainy season was not helpful for incumbents, because any aid associated with it was disbursed after the election. This supports the argument that the first rainy season — which took place before the election - had an impact on electoral outcomes, because incumbents used aid strategically to acquire votes.

If the lethality of disasters has a negative impact on leaders' survival in democracies, and given that Colombia has a long tradition of democratic rule, why is it then the case that exposure to floods and landslides had a positive impact for incumbent parties in the 2011 election? As previously stated, the basic mechanism proposed in this paper links disasters to political survival through clientelism. Data on the Colombian disaster allows for the disaggregation of relief between food and infrastructure aid. Municipalities receiving higher amounts of food aid per capita are associated with higher probabilities of reelecting the incumbent party. An equivalent association with infrastructure aid is not found. This suggests that particularistic goods, which are typically used for clientelistic transactions, have a clearer electoral impact than collective goods.

As previously mentioned, other explanations could account for the fact that there is a positive association between exposure to the disaster and electoral performance of the incumbent party. For instance, voters could reward the incumbent, because he efficiently handled the crisis. However, using a proxy for efficiency, it is demonstrated that there is no relationship between incumbency diligence and subsequent electoral performance. Also, citizens' levels of political engagement may change drastically after a traumatic event. For instance, voters affected by the disaster could become more interested in politics and turn out will increase. Thus, if supporters of the incumbent were more affected by the disaster than other voters, the subsequent increase in turnout would benefit the 
party in office. However, this alternative explanation is also ruled out, because it is demonstrated that victimization has no correlation with voter turnout. Therefore, it is not true that those citizens who are more heavily influenced by the disaster will present with an increase in the turn out to vote.

This paper is comprised of seven sections, including this introduction. Section 2 reviews the literature on the political economy of natural disasters with a particular emphasis on how these events affect electoral outcomes and, therefore, can be used strategically by political actors. Background information pertaining to the 2010-2011 rainy season in Colombia, as well as information on the 2011 local elections is provided in section 3. Section 4 describes the empirical strategy employed within this paper, founded on a difference-in-differences estimation complemented by an instrumental variables approach. Section 5 describes the data and its sources. Meanwhile, the main results of the paper are reported in section 6 , including the basic specification, the instrumental variables estimations, some tests of the mechanism, and the validity of alternative explanations. Finally, section 7 provides the concluding discussion for the paper, as a whole.

\section{Literature}

The political economy of natural disasters has focused on explaining the variation in the lethality of natural disasters (Anbarci et al. (2005), Cohen and Werker (2008), Kahn (2005), Quiroz and Smith (2010), Raschky and Schwindt (2009), Stromberg (2007), Toya and Skidmore (2007)). In general, these papers argue that the nature and quality of political institutions greatly affect the number of victims caused by a disaster. While some papers focus on cross-national data that includes many types of disasters (Kahn (2005), Stromberg (2007), Quiroz and Smith (2010)), others focus on specific events, such as earthquakes (Escaleras et al. (2007), Brancati (2007), Keefer et al. (2010)), hurricanes (Abney and Hill (1966), Chen (forthcoming), Chen (2011)), or floods (Mustafa (2003), Congleton (2006), Eisensee and Stromberg (2007), Fair et al. (2014)).

This paper is situated within the literature on the political legacies of natural disasters. Previous work suggests that voters punish incumbents that do a poor job at implementing disaster relief policies. Achen and Bartels (2004), for instance, argue that hard times tend to threaten governments, "even in situations where objective observers can find little rational basis to suppose that those incumbents have had any part in producing the voters' pain" (p.9). The authors show how shark attacks and floods and droughts can have a substantial negative impact on incumbent performance. Using the 1916 U.S. presidential race as a case study, Achen and Bartels (2004) show that a series 
of shark attacks in New Jersey during the summer of election year significantly reduced President Woodrow Wilson's votes in the presidential election that took place in the fall. The attacks caused deaths, but more importantly for their analysis, created considerable emotional and financial distress to entire communities, as the revenues of the tourism industry dropped rapidly. Citizens blamed the government for their misfortune, even if the attacks were not the fault of the government or any governmental entities.

In spite of the fact that the findings of this paper (a disaster might be beneficial for an incumbent) completely differ from Achen and Bartels' (2004) results, it is not necessarily the case that both stories contradict to each other. The authors recognize that it is possible that voters might have blamed the government for not helping them with their economic distress. From hindsight a century later, it is not hard to conclude that extending welfare benefits and unemployment compensation would have helped. Nonetheless, it is important to remember that many of these social programs that characterize welfare states today did not exist back in 1916. Therefore, a tragedy like the New Jersey shark attacks was not used in favor of the federal government precisely because the relevant clientelistic channels were not at the disposal of incumbent political leaders of the time.

Many studies analyzing the political effects of natural disasters identify accountability as a basic characteristic of democratic countries that motivates politicians to carefully treat situations in which the welfare of citizens is threatened. Healy and Malhotra (2009) show that there is a discrepancy between the electorates' reaction towards relief spending and preparedness spending. Voters reward politicians' efforts to ameliorate the consequences of a disaster that already occurred, but are relatively indifferent towards efforts to prepare ex ante to these events. Overall, some of the results of Healy and Malhotra (2009) are consistent with the findings of this paper, as they show that in the U.S. delivery of particularistic goods to affected populations is beneficial for incumbents. In fact, the authors suggest that preparedness spending has no electoral benefits, contrary to relief spending, because of the collective nature of the former versus the particularistic flavor of the latter. In this paper, a similar result is found, as allocation of food aid (particularistic spending) increases incumbent parties' likelihood of reelection, while infrastructure aid (collective spending) has no clear effect.

Other theories suggest that political institutions mediate the electoral consequences of natural disasters. Quiroz and Smith (2010) frame the analysis in terms of the selectorate theory (Bueno de Mesquita et al. 2003). For these authors, the occurrence and lethality of disasters have divergent effects on political survival of autocratic versus democratic leaders, as a consequence of the divergent 
sizes of the coalitions that hold politicians accountable. The authors find that in large coalition systems, such as democracies, where mass support is required to retain office, the lethality of a disaster, and not its occurrence per se, has a direct negative effect on political survival. For autocrats the situation is different, as the occurrence of disasters serves as a coordination device for protests that might end up removing the leader, while lethality of disasters has no significant effects. Framing the Colombian case within this theory, it is clear that the analysis corresponds to a democracy in which politicians need the support of large coalitions to remain in power. Nonetheless, in contrast to developed countries, the clientelistic nature of the political system in this developing country reduces the size of this winning coalition, such that the delivery of particularistic goods to strategic agents (i.e. the allocation of relief spending to influential local intermediaries) attenuates the pervasive electoral effects of disasters' lethality, even making them beneficial for democratic leaders.

This paper is also closely related to the literature on the strategic use of relief spending and humanitarian aid for electoral purposes. These types of arguments generally rely on the theory of retrospective voting (Fiorina 1981, Ferejohn 1986), arguing that voters reciprocate in the polls towards the plight of politicians that pursue actions that increase their welfare. Chen (forthcoming) uses information from disaster assistance that pertains to the summer of 2004 hurricane season in Florida for the purpose of demonstrating that awarding Federal Emergency Management Agency (FEMA) aid to the challenger party's voters reduces their turnout, while distribution of aid to the incumbent party's supporters augments it. Moreover, the author finds that aid delivered a week before the November of 2004 presidential election has a big effect on turnout rates, while aid distributed a week after has no impact.

Overall, from Chen's paper it is possible to infer that the 2004 hurricane emergency was beneficial for the incumbent (Republican) party and, as a consequence, aid can be used to strategically suppress opposers' turnout and to increase supporters' participation. As in his paper, I show that pre-election aid has an impact on political outcomes, while post-election relief has no effect. Nonetheless, I go even further because I analyze the effects of different types of aid and I use an instrumental variables approach to improve the identification strategy. In a related piece (and using the same natural disaster in the U.S.), Chen (2011) shows that the effects of FEMA aid distribution not only differs across partisanship, but also as a function of voters' income. Using a sample of Republican voters registered in Florida that applied to FEMA aid after the 2004 hurricane season, the author finds that middle-income voters react positively to the transfers, while the rich and the poor are relatively 
indifferent. These findings suggest that incumbents can strategically target the allocation of relief transfers across income groups.

\section{Background}

\subsection{Colombia's 2010-2011 Rainy Season}

President Juan Manuel Santos described the 2010-2011 rainy season as the worst natural disaster in the history of Colombia. ${ }^{1}$ As a tropical country, Colombia is comprised of both wet and dry seasons, whose duration and intensity is determined by a series of climatological phenomena that take place during the year. Of particular importance for understanding Colombia's current weather is the oceanatmosphere phenomenon known as "La Niña", which forms part of the broader "El Niño Southern Oscillation" (ENSO) pattern. La Niña corresponds to a drop in the sea surface temperature across the equatorial Eastern Central Pacific Ocean in front of the coasts of Peru, Ecuador, and Colombia (IDEAM 2011). A significant increase in rainfall takes place, particularly in the Pacific, Caribbean and Andean regions of the country, as a function of this decrease in temperatures combined with wind patterns.

Even though this phenomenon occurs on a yearly basis, the event that started in the second semester of 2010 and persisted until at least April of 2011 is considered the most intense in history. During this period, rainfall registered unprecedented levels with values that presented 170 percent above regular numbers (Sanchez, 2011). Extreme rainfall did not plague a particular region of the country, but struck with a varying intensity through 28 out of the 32 departamentos ${ }^{2}$ and 93 percent of the municipalities.

An increase in the river levels was a direct consequence of the heavy rain. Colombia's hydrology is one of the most abundant and complex around the world with almost every municipality having access to a significant body of water. As a result, floods were a common event, causing damage and loss for the affected population. In addition, given the complex topography of the nation and the fact that an important proportion of its habitants are located in the Andean region, landslides caused by the accumulation of water and sediments in the ground were the other major source of affectation.

According to official records, ${ }^{3}$ the 2010-2011 La Niña rainy season phenomenon affected about 4

\footnotetext{
${ }^{1}$ See http://www.semana.com/nacion/peor-tragedia-natural-historia-del-pais/155398-3.aspx

${ }^{2}$ Departamentos are analogous to States in the U.S., although Colombia's political system is far more centralized.

${ }^{3}$ See http://www.regiones.gov.co/FenomenoNina/Fenomeno-Nina_110714.pdf.
} 
million citizens (more than 8 percent of the population), with 490 human deaths, 595 people injured, 12,908 houses destroyed and 441,579 affected, as well as 1,080,000 hectares of productive land flooded (Sanchez (2011)). The Colombian disaster was not very lethal in terms of human loss, but it had enormous social and economic impact measured by the number of people affected and the total property destroyed. Figure 1 depicts the spatial distribution of this Colombian disaster. In terms of the number of people affected, this event was particularly intense in the Pacific, Caribbean, and Andean regions of the country.

Compared to other natural disasters around the world, this type of impact is common to events that result from heavy rain and floods. For instance, using data from the Emergency Events Database (EM-DAT), Stromberg (2007) documents that from 1980 to 2004, a total of 621 earthquakes occurred in the world, causing approximately 215 million deaths and affecting 78 million. In contrast, 2102 floods took place in the same period, causing 171 million deaths, but affecting 2490 million people. Hence, while other disasters are more lethal in terms of fatalities, floods like the ones that took place in Colombia have higher levels of affectation.

The significant impact of the disaster led President Santos to create "Colombia Humanitaria", a National-Level Agency in charge of raising and distributing aid to the affected communities. For this purpose, the government implemented a three-stage strategy that includes humanitarian aid, reconstruction, and rehabilitation. More than US $\$ 3.5$ billion were raised and distributed from the central government to local authorities (at both the Departamento and Municipality levels). Most of the resources were distributed to mayors, and for that reason this paper focuses on that election. In addition, the disaster received substantial media coverage and captured the attention of the entire country, explaining why Colombia Humanitaria is considered the most successful humanitarian campaign in history, at least in terms of the amount of donations raised. ${ }^{4}$

\subsection{The 2011 Local Elections}

This season of above-average rainfall and the associated number of floods and landslides, extended until the midst of 2011. Later that year, on October 30th, local and regional elections took place with more than 130,000 citizens running for governor, mayor, or local councils. Elections for these offices took place in the country's 32 departamentos and in more than 1100 municipalities. Until 1988 mayors in Colombia used to be centrally appointed. Now they are elected by universal suffrage and since

\footnotetext{
${ }^{4}$ http://www.semana.com/nacion/colombia-humanitaria-campana-donaciones-historia-del-pais/159024-3.aspx.
} 
then local governments have been given increased responsibilities and powers to raise local revenues. In this sense, the mayor is a central figure in advancing the interests of the municipality. Being a multi-party system, immediate reelection of mayors (the main focus of this paper) is prohibited in Colombia. For this reason, reelection of the incumbent party is used as a measure of political survival.

Election day was relatively calm, although illegal armed groups (comprised by guerrillas and paramilitaries) once more tried to interfere and alter the normal conduct of elections (Gallego (2011)). Given the overlap between the political campaign associated with this election and the humanitarian efforts aimed at ameliorating the impact of the disaster, several institutions monitoring the process warned about the possibility of candidates using aid strategically for electoral purposes. ${ }^{5}$ The goal of this paper is to show that these warnings were not completely misguided.

\section{Empirical Strategy}

To determine the causal effect of the natural disaster on party survival in Colombia, this paper emphasizes the fact that the 2010-2011 rainy season was not concentrated on a particular region, but instead exhibited spatial variation across the country. Therefore, it is possible to claim that the intensity of rainfall, and to some extent, the occurrence of disasters, such as floods and landslides, are exogenous to the political process and to electoral results. Different approaches will be used, in order to measure a municipality's level of exposure to the disaster. In the basic specification, the rate of victims per capita will be used. Given that floods and landslides are mainly caused by events of extreme rainfall, in other cases exposure to the disaster will be quantified through precipitation measures.

In this paper, a difference-in-differences estimator is utilized, in order to compare party survival in municipalities heavily and weakly affected by the disaster, before and after it occurred. For this purpose, this research controls for municipality and year fixed effects in a linear regression. Municipality fixed effects control for any specific characteristics that do not change over time and that might affect the probability of reelection or the vote share of an incumbent party, such as historical conditions or geographic characteristics of the municipalities. ${ }^{6}$ Time effects control for

\footnotetext{
${ }^{5}$ See, for example, http://www.semana.com/enfoque/emergencia-invernal-riesgo-electoral/153227-3.aspx or http://www.semana.com/nacion/contraloria-desviacion-recursos-invierno-bacrim-mayores-riesgos-electorales/1573053.aspx.

${ }^{6}$ See for instance Losada, Giraldo, and Muñoz 2005, where it is claimed that the Liberal party tended to have more
} 
specific events that occurred in a particular year and that equally affect every municipality, such as any political reform that might have changed the rules of the game for a particular election or certain economic characteristics that caused an impact across the country. In this context, the basic specification estimated is as follows:

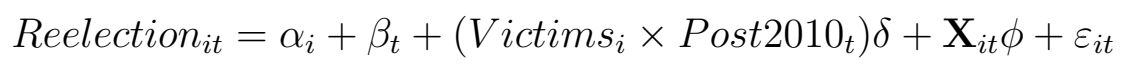

where Reelection $i t$ is a dummy variable indicating if the incumbent party won the mayoral election in municipality $i$ at election year $t$, for $t=2007,2011$. Furthermore, $\alpha_{i}$ controls for municipalitylevel fixed effects while $\beta_{t}$ for time effects. $\mathbf{X}_{i t}$ is a vector representing time-varying municipality level controls. In this case and to avoid potential endogeneity caused by the inclusion of posttreatment covariates, I include pre-disaster fixed values of different controls, and interact them with a post-disaster time dummy $\left(\right.$ Post $\left.2010_{t}\right)$. This vector includes demographic controls (population and population density), a climatological control (temperature), ${ }^{7}$ and a socio-economic control (poverty). Finally, $\varepsilon_{i t}$ represents the error term for municipality $i$ at election-year $t$.

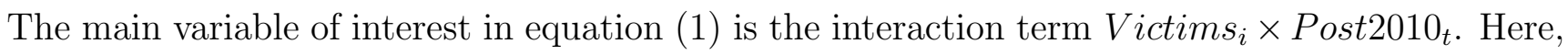
Victims $_{i}$ is the number of victims per capita in municipality $i$, as a consequence of the 2010-2011 rainy season in Colombia. Post $2010_{t}$ is a dummy variable, which indicates if the event (election) analyzed took place before or after the disaster. Given that we only have two years, Post2010 $t$ also represents the year effects. Therefore, the coefficient of interest in this specification, $\delta$, measures the effect of the disaster on incumbent party reelection in 2011, as compared to the 2007 contest. Note that the constituent terms of the interaction, Victims $s_{i}$ and Post $2010_{t}$ are absorbed by the fixed and time effects respectively, and do not appear separately in (1).

It can be claimed that Victims $_{i}$ is not exogenous to municipality-level observable or unobservable characteristics. For instance, it is likely that in poor and unequal municipalities, more families will live in zones prone to floods and landslides, such as riverbanks or hillsides. Therefore, municipalities highly affected by the disaster would differ from weakly affected ones on other (possibly) non-observable characteristics, making more difficult the identification of causal effects. This fact

support around the coasts (Pacific and Atlantic), while the Conservador party used to have more support in inner and mountainous regions.

${ }^{7} \mathrm{~A}$ geographical control such as altitude could also be included. However, the correlation between temperature and altitude is almost perfect (-0.9832) in Colombia, with elevated places exhibiting lower temperatures, and vice versa. 
would be troublesome if such characteristics exert a differential impact post 2010. For instance, if poorer places voted differently in 2011. In order to account for this potential endogeneity concerns, a primary identification strategy employed in this paper is to utilize a plausibly more exogenous measure of municipality exposure to the disaster. Landslides and floods are more likely to occur when extreme climatological events take place, such as episodes of heavy rain in short periods of time. $^{8}$ Therefore, an alternative specification estimated in this paper is as follows:

$$
\text { Reelection }_{i t}=\alpha_{i}+\beta_{t}+\left(\text { Rainfall }_{i} \times{\text { Post } 2010_{t}}\right) \gamma+\mathbf{X}_{i t} \phi+\varepsilon_{i t}
$$

where all variables and parameters are defined as in equation (1). The difference between (1) and (2) is that, in the second specification, exposure to the disaster is captured by the variable Rainfall $_{i}$, which quantifies events of extreme rainfall at the municipality-level. This variable measures, in millimeters, the maximum level of rainfall in 24 hours experienced by municipality $i$ during the six months between October of 2010 and March of $2011 .^{9}$ The rationale behind this measure is that in those places in which it rained more during a whole day, the probability of having subsequent floods and landslides (and hence more victims) is also higher.

Nonetheless, a climatological variable, such as extreme rainfall level, might be correlated with agricultural production, which in turn could easily affect the political preferences of voters. Given this correlation, failure to control for agricultural output would generate biased estimates of the causal effect of the disaster on electoral outcomes. Therefore, this paper employs an instrumental variables (IV) approach, using an exogenous source of variation correlated with the number of victims per capita and uncorrelated with the error term. For this purpose, water supply per capita at the municipality level is used to calculate the number of victims, as measured by hydrologists that used the National Water Study (IDEAM (1998)), more than a decade before the disaster. This variable measures surface runoff, which is an estimation of the volume of water contained in water bodies (rivers, lakes, ponds, etc., not the ocean) and groundwater. Naturally, municipalities with bigger rivers or lakes tend to have a higher supply.

Water supply (interacted with the time dummy) is a valid instrument for victims of floods and landslides (also interacted) if it is not weak and if the exclusion restriction is satisfied. As will be shown below, it is not weak being that an increase in supply predicts an increased likelihood of floods

\footnotetext{
${ }^{8}$ See the definition and description of floods given by the Colombian central government at http://www.sigpad.gov.co/sigpad/paginas_detalle.aspx?idp=144

${ }^{9}$ This was a period of high levels of precipitation intensity.
} 
and, hence, more victims. In terms of the correlation with agricultural activities, it is not expected to be as high as in the case of rainfall, because this variable simply measures the volume of water contained in rivers. An interesting feature of Colombia's geography is that almost every municipality has a river, therefore this variable is not an indicator of whether a population has access to a body of water as a transportation or economic source. It simply measures the volume of water surrounding a place, which in part is the result of topographic characteristics, such as the size of the hydrographic basins that, perhaps, are exogenous to covariates affecting any political outcome.

Defining Water $_{i}$ as the average level of water supply per capita in municipality $i$ before the disaster, the first stage of the IV approach estimates the following:

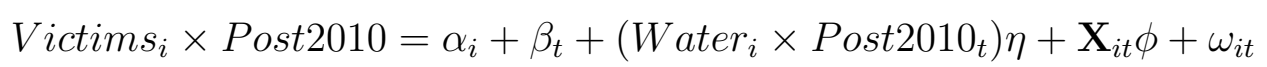

While the second stage is given by:

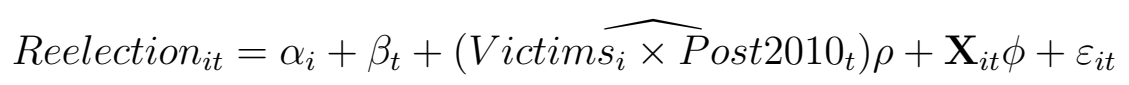

where Victim $_{s_{i} \times \text { Post }} 2010_{t}$ are the predicted values that result from equation (3). Naturally, $\eta$ is expected to be positive, as floods are more likely to occur in places with more water surrounding. Additionally, in order to test the mechanism -that disasters generate a flow of resources to local authorities that is used to buy votes and consequently augments the probability of reelection- two additional types of specifications are estimated. First:

$$
\operatorname{Aid}_{i}=\alpha+\text { Victims }_{i} \beta+\mathbf{X}_{i} \phi+\epsilon_{i}
$$

where $A i d_{i}$ is a measure of disaster relief allocated by the central government in 2011 through the Colombia Humanitaria project to municipality $i$. Two aid measures are employed: food and infrastructure. Clearly, (5) is a cross-sectional estimation of the correlation between the number of victims per capita and the subsequent amount of aid per capita received. To show that such aid increases incumbent party's likelihood of reelection, I estimate 


$$
\operatorname{Pr}\left(\text { Reelection }_{i}\right)=\Phi\left(\alpha+\text { Food }_{i} \beta_{1}+\text { Infrastructure }_{i} \beta_{2}+\mathbf{X}_{i} \phi+\varepsilon_{i}\right)
$$

where Food $_{i}$ and Infrastructure $i$ are measures of the amount of food and infrastructure aid per capita received by municipality $i$, while $\Phi(\cdot)$ represents the cumulative distribution function of the standardized normal distribution. Therefore, a probit regression is utilized when estimating (6).

Summing up, this section described the basic identification strategy used in this paper, that employs a difference-in-differences estimation of the effect of the disaster on party survival. An instrumental variables approach complements this strategy and different estimations are used to test the robustness of the results and the validity of the mechanism.

\section{Data}

\subsection{Data Sources}

Victim-related data used in this study comes from the National Administrative Department of Statistics (DANE). A few weeks after the disaster took place, and for the purpose of quantifying its effects, DANE developed the Unique Record of Victims. According to this record, victims are "people that have suffered serious damage associated directly to the event: partial or total loss of goods (estate, livestock or crops) and/or disappearance, injury or death of family members" (DANE (2011), p. 11). In order to control for municipality size, the total number of victims is divided by the total population. Therefore, the variable Victims $_{i}$ used below corresponds to the number of victims per capita in municipality $i$ as a consequence of the 2010-2011 wet season in Colombia.

Rainfall data comes from the Hydrology, Meteorology, and Environmental Studies Institution (IDEAM), which is the official Colombian government environmental agency. This institution registers rainfall on a daily basis, using more than 2500 pluviometric stations located across the country. Given that in Colombia there are about 1200 municipalities, and for some there is more than one station, while for others there are none, this study geo-referenced both stations and municipalities, calculated the distance between each, ${ }^{10}$ and determined the nearest one. As it was described above, the variable Rainfall $_{i}$ is a measure of extreme climatological events, and corresponds to the maximum level of rainfall in 24 hours, measured in millimeters, registered for municipality $i$ from October

\footnotetext{
${ }^{10}$ For this purpose, Stata's Vincenty package was used (Nichols, 2003).
} 
of 2010 through March of 2011. ${ }^{11}$ Water supply, which is an estimate of surface runoff of major water bodies and groundwater of Colombian municipalities, is measured by IDEAM and is reported in the National Water Study (IDEAM (1998)). Measured in millions of cubic meters, this variable represents the average volume of water available for Colombian municipalities during a regular year. ${ }^{12}$

Other disaster-related variables include total aid allocated to affected municipalities. This information comes "Colombia Humanitaria", the national agency created by the central government after the crisis for the purpose of facilitating assistance to victims. ${ }^{13}$ Two types of humanitarian aid are analyzed in this paper: food relief (measured as the number of grocery and hygiene kits per capita allocated to affected municipalities during or weeks after the disaster) and infrastructure aid (measured as the amount of money per capita in Colombian pesos allocated to municipalities to construct or rebuild infrastructure assets destroyed by the disaster or new ones to prevent future damage). To measure the efficacy of local governments in facilitating these projects, a dummy variable called Delays is constructed, based on information provided by the Attorney's Office. ${ }^{14}$ The report lists municipalities that were investigated in September of 2011 (one month before the election), because of delays and other irregularities in the execution of these projects (Procuraduría General de la Nación, 2011).

Municipality-level covariates include pre-disaster values for demographic, climatic, and socioeconomic controls. Demographic controls include levels of population and population density in 2007, as measured by DANE. The climatic covariate is average temperature in Celsius and is also provided by DANE. Finally, this research uses poverty to control for socio-economic characteristics, measured as the proportion of citizens with unsatisfied basic needs. ${ }^{15}$ This index is constructed by the National Planning Department (DNP). Lastly, electoral variables for the 2007 and 2011 local elections are derived from the National Registry, the official Colombian government electoral agency.

\footnotetext{
${ }^{11}$ This particular range is chosen because of its intensity and data availability.

${ }^{12}$ Regular years are defined as those in which surface runoff corresponds to the average multi-year value of historical series of representative flows (IDEAM (1998), p. 16).

${ }^{13}$ See http://www.colombiahumanitaria.gov.co/Paginas/QueesColombiaHumanitaria.aspx.

${ }^{14}$ Procuraduria General de la Nacion.

${ }^{15}$ In Spanish the index capturing this number is called NBI, for Índice de Necesidades Basicas Insatisfechas.
} 


\section{Results}

\subsection{Basic Specification: Difference-in-differences Approach}

I begin by presenting a graph that summarizes the basic empirical strategy followed in this paper. The main idea is to compare the proportion of municipalities in which the incumbent party got reelected in 2007 and 2011, in places "affected" and "not affected" by the 2010-2011 disaster. In Figure 2 municipalities affected by the disaster are those whose number of victims per capita are above the 80 th percentile. ${ }^{16}$ The graph shows that in 2007 , before the disaster occurred, a similar proportion of municipalities in both groups saw the incumbent party win again the mayoral election. However, the situation is quite different months after the disaster took place: with 2007 as a reference, there is a sharp increase in the proportion of municipalities heavily affected by the disaster where the incumbent party won, whereas this proportion remains stable (decreases a bit) for municipalities not affected. ${ }^{17}$

The rationale behind this analysis is that if the disaster had not occurred, reelection patterns in municipalities affected and not affected would have followed a common trend, and consequently the difference in the actual trajectories is the causal effect of the disaster that wants to be determined. Figure 2 suggests that the disaster caused an increase in the probability of reelection in affected municipalities compared to those not affected, in 2011 relative to 2007.

Table 1, which reports estimations for different specifications based on (1), corroborates these results. Every specification includes municipality-level fixed effects, time effects, and standard errors are clustered at the municipality level. Recall that the coefficient of interest is $\delta$, the parameter associated to Victims $\times$ Post2010. As columns 1-4 reveal, the positive and significant coefficients of the different specifications suggest that in 2011 the increase in the probability of reelection is higher in municipalities more affected by the disaster. In other words, an increase in the rate of victims significantly increases the probability of reelection, in 2011 relative to 2007. Column 1 reports the estimates when municipality-level controls not are used; column 2 shows that the result is robust

\footnotetext{
${ }^{16}$ The shape of the figure and the intuition holds for lower and higher thresholds.

${ }^{17}$ Analyzing this graph is might seem surprising that the average value for Reelection is quite low. Recall that this variable indicates whether or not the incumbent party was reelected in the 2007 and/or 2011 mayoral elections. Surprisingly, incumbents were reelected in only 16 per cent of the elections. This outcome supports the burgeoning literature that claims there is an incumbency disadvantage in developing countries (Brambor and Ceneviva (2011), Klasnja (2012), Linden (2004), Titiunik (2009), Uppal (2009)), in contrast to the robust finding that incumbency advantage prevails in developed nations (Ansolabehere et al. (2000), Erikson (1971), Ferejohn (1986), Gelman and King (1990), Hainmueller and Lurz-Kern (2008), Horiuchi and Leigh (2009), Katz and King (1999)). In the Colombian case, incumbency disadvantage and this low proportion of effective reelections may be a consequence of the weakness of political parties (Gutierrez (2007))
} 
to the inclusion of demographic -population and population density-controls; column 3 includes temperature; and column 4 incorporates poverty. In every case the result is the same: a positive and significant coefficient for the interaction between the rate of victims per capita and the post-disaster dummy variable.

The estimates imply substantial effects. For instance, the coefficient in column 1 suggests that a 1 percentage point increase in the rate of victims per capita increases the probability of reelection by approximately $.23 \%$ in 2011 . Thus, compared to a situation with no victims, a municipality in which the whole population was affected experiences an increase in the probability of reelecting the incumbent party 23 percentage points higher in 2011.

Endogeneity could bias the results presented above if our main variable of interest, Victims $\times$ Post2010, is correlated with error term $\varepsilon_{i t}$ in (1). This situation could be the case, for instance, if municipalities with higher levels of income inequality have more habitants living in zones prone to floods and landslides, such as riverbanks or hillsides. If inequality also predicts whether an incumbent party is reelected, estimates based on (1) would be biased. Another cause of endogeneity and biasedness could be measurement error. For instance, it could be the case that municipalities governed by corrupt politicians tend to over-report the number of victims just for the sake of obtaining

more aid. If there is a correlation between this source of measurement error (more victims registered than real victims in "corrupt municipalities") and the likelihood of reelection, the estimates based on (1) would be biased.

Essentially, the problem of using the number of victims per capita as a measure of disaster exposure, is that this variable might be correlated with a big number of political and economic covariates that might also affect electoral outcomes. Consequently, endogeneity is less of a concern if an exogenous variable correlated with the exposure of municipalities to the disaster is utilized instead. Given that high levels of precipitation are the natural events that mainly cause floods and landslides, which in turn cause victims, extreme rainfall is a natural variable to be analyzed, as suggested by (2). The effects of extreme rainfall episodes on the probability of reelecting the incumbent party are reported in the On-line appendix.

\subsection{Instrumenting for Victims: Water Supply of Municipalities}

Even though it is difficult or impossible to claim that political or economic variables explain the variation in extreme rainfall levels, the opposite might be true. Rainfall can be correlated with eco- 
nomic production, as several agricultural activities, not necessarily captured by the controls included in this paper, heavily depend on levels of precipitation. In fact, some authors use rainfall as an instrument for economic growth to explain levels of civil conflict (Miguel et al. (2004)). Therefore, if the performance of economic activities predicts electoral outcomes and party survival, estimations based on (2), once more, might be biased. To account for these potential endogeneity bias, in this section I present an alternative approach: the use of a hydro-topographic variable as an instrument for levels of victimization associated to the 2010-2011 disaster.

Colombia is a great power in terms of water supply. Besides being the only South American country with access to both the Atlantic and Pacific oceans, all across its territory several rivers and lakes are found and serve as suppliers of water to the population. In fact, it is difficult to find municipalities without access to water bodies. Naturally, accessibility to this important natural resource is not only a function of rainfall. It also depends on topographic characteristics, which determine the size river basins and soil accumulation, which in turn determine the levels of water supply available for a municipality. Given that most of the victims of the disaster analyzed in this paper suffered from floods that destroyed their homes, crops, lands and other properties, and that these events are not only a function of rainfall but also of the existence and abundance of surrounding water bodies, availability of water per capita will be used as an instrument for victimization.

Naturally, for water supply to be a valid instrument it is also necessary that the only channel through which the interaction of water and the post disaster time dummy affects reelection results, is through its effect on the interaction of victims and such time dummy. It could be claimed that water supply affects the places where people choose to live. It is for this reason that I use per capita levels in this analysis; in fact, the correlation between water supply per capita and population density is weak and statistically insignificant (results not reported). It could also be claimed that water supply affects economic activities, as in the case of rainfall. Nonetheless, given the nature of the instrument described in (3), for this concern to be valid, it would be necessary to explain why is there a differential effect of water supply on these activities in 2011 as compared to 2007, for a reason different to the disaster itself. Besides, as it was mentioned before, water supply is not an indicator of whether a Colombian municipality has access to a river or a lake for agricultural or transportation reasons, because most municipalities have access. Consequently, the basic assumption behind the use of Water $\times$ Post2010 as an instrument for Victims $\times$ Post2010 is that water supply measures the size and presence of water bodies that may cause floods after high levels of precipitation. 
Table (2) reports the results of the instrumental variables estimation based on (3) and (4). The estimates reveal that the findings presented above are robust to the instrumental variables approach. Second stage results show that in 2011, as compared to 2007, higher rates of victimization caused a higher increase in the probability of reelecting the incumbent party. This finding is robust to the inclusion of demographic controls (column 2), climate (column 3), and poverty (column 4). The coefficient in column 1 suggests that a 1 percentage point increase in the rate of victims per capita increases the probability of reelection by approximately $.45 \%$ in 2011 . Thus, compared to a situation with no victims, one in which the whole population was affected implies an increase in the probability of reelecting the incumbent party 45 percentage points higher in 2011.

First stage results also conform to the expectations. After the disaster, municipalities with higher levels of water supply are predicted to have higher levels of victims per capita. In every specification, an $\mathrm{F}$ value higher that 40 corresponding to the Kleibergen-Paap test provides evidence to reject the null hypothesis that the instrument is weak. Overall, results reported in table 2 suggest that municipalities surrounded by more voluminous rivers are lakes are more likely to experience floods, and that a place that had more victims exhibits a higher increase in the probability of reelecting the incumbent party in 2011.

In this section an instrumental variables approach has been used to complement the differencein-differences strategy proposed above and to determine the causal effect of exposure to a natural disaster on the probability of reelection of the incumbent party. Using water supply, interacted with the post-disaster time dummy as an instrument for the number of victims interacted with this time dummy as well, I find that the disaster caused an increase in incumbent parties' survival in 2011 in municipalities heavily affected by floods and landslides. In the next section I present evidence supporting the basic mechanism proposed in this paper.

\subsection{Mechanism: Humanitarian Aid Increases Clientelism?}

If a disaster diminishes the well-being of those affected, why would it be beneficial for a democratic leader? The mechanism proposed in this paper suggests that after a disaster not only affected citizens have a higher propensity to sell their votes: incumbents will also have higher budgets and more resources to buy those votes. In order to test this hypothesis the paper presents two pieces of evidence, based on information provided by Colombia Humanitaria, on the allocation of different types of humanitarian aid among affected municipalities. 
During the disaster, and weeks after it ended, the central government, through the Colombia Humanitaria agency, distributed food aid to the affected population, in the form of grocery and hygiene kits. Figure A1 and table A7, both in the On-line Appendix, show that the correlation between food aid and victims of the disaster is positive, suggesting that at least in terms of the allocation of particularistic aid -as food and hygiene kits- the government gave more to those with more needs.

The disaster not only affected citizens directly through the loss of human lives, homes, or livestock. It also destroyed roads, bridges, and other infrastructure assets, which naturally increased the economic costs to the affected communities. For this reason, Colombia Humanitaria allocated a fair amount of humanitarian aid for the purpose of reconstructing local public goods destroyed by the disaster, and for the construction of dikes and other structures that could prevent future floods and landslides. Figure A5 and Table A8, both in the On-line Appendix, illustrate that the correlation between the amount of money per capita allocated to infrastructure projects to mayors in each municipality, and the number of victims per capita is positive, although it is weaker. This situation is not surprising, because even though we would expect that places with more victims will also have more destroyed infrastructure, the relationship would not necessarily be perfect. Some places might have a lower number of victims but more costly local public goods destroyed. This evidence could be the result of divergent costs of reparation of local public goods (bridges, roads, etc.), or could be caused by an inefficient and perhaps politically oriented allocation of resources. However, without a quantification of the economic damage caused by the disaster at the municipality level, it is hard to determine the real cause of this discrepancy.

As in the case of food relief, is it true that high levels of infrastructure aid increase the likelihood of reelection in 2011 for incumbent parties? Facts and intuition suggest that in this case things are not so simple. Even though Colombia Humanitaria allocated resources before the election took place, most of these projects, for different reasons, were not executed before October 30th, 2011. Therefore, not all of the money was available during the electoral campaign, as opposed to grocery and hygiene kits that were distributed before election day.

Columns 1-4 in table 3 report the estimates of a series of cross-sectional probit regressions of reelection in 2011 on these different forms of aid. The results reveal that high levels of food aid predict higher probabilities of incumbent party reelection in 2011. No significant effect on reelection is found for infrastructure aid. As usual, these results are robust to the inclusion of population, population 
density, temperature, and poverty controls. Hence, these estimations reveal that particularistic benefits, such as food, have a positive impact on party survival, while collective goods, such as infrastructure aid, have no effect. These results support the mechanism proposed in this paper. As defined and discussed in Gallego (2014), political clientelism is a dyadic relationship in which a politician (the patron) offers private goods or services to the voter (the client) in exchange for political support, which generally includes the vote. In this case, voters receive private rewards in the form of food aid. Incumbents, in the meantime, are more likely to win in places more affected by the disaster and where more relief was allocated. Does it mean that relief is being allocated strategically to gain votes and win elections? In the following subsections I present evidence supporting such claim.

\subsection{Why Clientelism?}

The first piece of evidence in favor of the argument that parties allocated aid strategically in order to get votes uses information from the Office of the Inspector General of Colombia. This institution oversees the public conduct of those in authority, including Mayors and Governors. Before the election, several analysts, NGOs, and the media warned about the possible use of relief with electoral purposes. ${ }^{18}$ In fact, the Office of the Inspector General investigated irregularities in more than 200 municipalities. ${ }^{19}$ Most of these irregularities are related to the allocation of food aid. Some of the motivations for conducting these investigations include "irregular management of humanitarian aid", "alleged utilization of resources for electoral purposes", "allocation of aid to non-victims", or "allocation of aid in exchange for votes." In other words, and following the definition stated above, the Office of the Inspector General investigated cases of clientelism.

If the mechanism proposed in this paper is correct, in places in which (there is evidence that) clientelism took place the probability of reelecting the incumbent party should be higher. For this purpose, I create a dummy variable that indicates whether an investigation by the Office of the Inspector General took place in the municipality. I only include cases in which the investigation took place because of irregularities in the allocation of resources. Models 5-8 in table 3 report the results of cross-sectional probit estimations in which the dependent variable is the probability of reelecting the incumbent party. Once more, only information for the 2011 election is used in these regressions. The results are quite interesting. The main variable of interest is Irregularities, and its associated coefficient is positive and significant on every specification. It means that in municipalities in which

\footnotetext{
${ }^{18}$ See, for instance, http://www.elespectador.com/noticias/politica/proselitismo-subsidios-articulo-302748

${ }^{19}$ See http://www.procuraduria.gov.co/portal/media/file/070911procesos.pdf
} 
investigations for irregularities in the allocation of aid took place, the probability of reelecting the incumbent party is higher.

Therefore, the results of this subsection reveal that it is not only true that places more affected by the disaster and that received more relief are more likely to reelect the incumbent party. It is also clear that in municipalities in which there is some official evidence of clientelism and votebuying through these resources, it is also more likely to reelect these parties. Politicians allocated aid strategically in order to win elections. And they were successful at doing so.

\subsection{A Placebo Test}

In this section a placebo test is performed in order to corroborate the hypothesis that the disaster increases the chances of reelection of the incumbent party. So far, data on affected population corresponds to victims of the first rainy season, which goes from the second semester of 2010 until April of 2011. However, after the election took place on October of 2011, a second rainy season occurred. Although it was less intense and severe than the first one, it also caused damage and high levels of victimization. For the placebo test, the number of victims per capita from November of 2011 through June of 2012 is utilized. Consequently, Victims After is interacted with the Post2010 dummy variable, in order to estimate an specification equivalent to (1). If the mechanism proposed in this paper is correct -that disaster affectation implies an inflow of resources that can be used for buying votes-, no effects on the probability of reelection should be found after estimating this new specification. Victimization after the election should have no impact on the probability of reelecting the incumbent party, because any relief allocated for new victims is ex-post to campaigning.

Table 4 corroborates the intuition. Columns 1-4 report the coefficients for the DID specification, using victims after the election as the main variable of interest, while columns 5-8 report the results for the IV approach. In any case, the results reveal the post-election disaster has no effect on the probability of reelecting the incumbent party. In municipalities more affected by the rainy season from November of 2011 until June of 2012 the change in the probability of reelection is not higher than in municipalities less affected. Hence, this placebo test corroborates the idea that what matters is the impact of the disaster previous to the election, as relief is used by incumbents to by votes. 


\subsection{Alternative Mechanisms}

So far the paper has shown that compared to the 2007 mayoral elections, in 2011 incumbent parties have a higher probability of being reelected in municipalities heavily affected by the natural disaster. This result is robust to different measures of disaster exposure: number of victims per capita or episodes of extreme rainfall in 24 hours; additionally, the result holds when water supply at the municipality level is used as an exogenous source of variation for victimization. Moreover, a basic mechanism has been proposed. The disaster is beneficial for incumbent politicians because it generates an inflow of aid and resources that can be used to buy votes. The patterns exhibited by food aid allocation and its impact on electoral results confirms this hypothesis. Nonetheless, alternative explanations could be proposed. The purpose of this subsection is to rule out these alternative justifications for the results encountered so far.

A first possibility would be that incumbent parties increase their probability of reelection after the disaster because they are efficient at alleviating the pervasive consequences associated to the tragedy, and consequently voters reward this efficiency at the polls. This alternative explanation is closely related to retrospective voting theories: voters punish incumbents that they consider diminished their well-being through their actions. On the contrary, if they consider that the incumbent policies increased in some way their satisfaction -and this would be the case for citizens affected by the disaster whose suffering is ameliorated or whose losses are diminished thanks to the efficient strategies implemented by the authorities- a natural way to reciprocate would be to support the party in office.

To test this mechanism it is necessary to employ a measure of effectiveness of local governments in alleviating the crisis. On September of 2011, about a month before the election, the Attorney's office published a list of municipalities that were being investigated because relief and prevention projects presented delays in their execution. Therefore, under the assumption that voters have knowledge of this situation -either because they have access to the list or because they are aware of the delays in their municipality- incumbent governments investigated because of their inefficiency in alleviating the crisis should exhibit a lower probability of reelection. Figure A6 in the On-line Appendix provides descriptive evidence against this assertion, as it shows that in municipalities with no delayed projects -according to the Attorney's office- the proportion of elections won by the incumbent party in 2011 is very similar to the analogous proportion in places that exhibit delays.

Furthermore, a series of cross-sectional Probit regressions, whose results are reported in columns 
1-4 in table 5, are employed to determine the relation between Delays -a dummy variable indicating if a municipality had any delayed projects- and the 2011 reelection indicator variable. The estimated coefficients are insignificant for every specification, suggesting that it is not necessarily true that inefficient governments -in terms of alleviating the effects of the disaster- are less likely to be reelected.

A second alternative approach is related to the political psychology of exposure to traumatic events. It can be argued that citizens' levels of political engagement changes drastically after they experience traumatic situations, such as the loss of family members or property due to a natural disaster. Two possibilities arise. Voters affected by the disaster could become less interested in politics and participate less, because their own tragedy consumes their time and reduces access to information about the electoral campaign. In such case, if -by chance or for any other reason- supporters of challenger parties are more affected, in the end this situation would benefit the incumbent party and the change in its probability of reelection should be higher in 2011.

Alternatively, an opposite mechanism could take place. Exposure to the disaster could increase affected citizens' level of political engagement. After suffering psychological and material damage, voters could become more interested in the political process. For instance, affected citizens could realize that the outcome of the election is crucial for the selection of future policies aimed to alleviate the pervasive consequences of the disaster. If, for any reason, supporters of the incumbent party are more affected, again the effect would be to see a bigger change in the probability of incumbent reelection in affected municipalities. In any case -whether the disaster augments political engagement of incumbent party supporters or decreases political engagement of opposers- the effect should be the same: a differential change from 2007 to 2011 in voter turnout in municipalities affected by the disaster.

If the traumatic events augment incumbent supporters' level of engagement, more people from this group should vote in 2011 and voter turnout should increase in relative terms. On the contrary, if the disaster decreases incumbent opposers' level of engagement, such group would vote less, so that turnout should exhibit a relative reduction. In any case, the explanation of why we see a differential change in the likelihood of reelection would differ from the clientelistic approach defended throughout this paper.

Figure A7, in the On-line Appendix, depicts the correlation between municipalities' number of victims per capita and voter turnout in the 2011 mayoral election. The graph reveals a very weak 
(if any) correlation between the two variables, situation that is corroborated by the standard crosssectional OLS regressions reported in columns 5-8 in table 5. Using 2011 data, it is clear that Victims is a very bad predictor of Turnout, suggesting that the disaster did not cause major shifts in citizens' levels of political engagement, whether they support or oppose to the incumbent party. ${ }^{20}$

This subsection presents evidence against alternative mechanisms for why incumbent parties experience a higher increase in the probability of reelection in municipalities affected by the disaster. First, it does not seem to be the case that voters are rewarding efficient politicians that through their behavior ameliorated the negative consequences of the disaster. Additionally, evidence does not support the idea that the disaster changed relative levels of political engagement among incumbent and challenger supporters.

\section{Conclusion}

Selectorate theory of political survival (Bueno de Mesquita et al. (2003)) suggests that the sizes of the winning coalition (the set of essential supporters without whose support a leader would lose power) and the selectorate (the set of people from which the winning coalition is formed) determine the political incentives that shape leaders' behavior. In larger coalition systems, like democracies, natural disasters that affect a big proportion of the population inevitably diminish the welfare of certain members of such winning coalition. For this reason, even if disasters are acts of God, citizens might punish incumbents that fail to invest in preparedness or that inefficiently allocate disaster relief. Consequently, political institutions have a direct effect on disasters' lethality, explaining why these events generally have more impact on autocratic regimes (Quiroz and Smith (2010)).

Nonetheless, not all democracies are the same and the size of winning coalitions differ across democratic countries. In particular, clientelism and bloc voting (Gallego (2014) and Smith and Bueno de Mesquita (2012)) are important traits of electoral systems that may significantly reduce the size of the winning coalitions of political leaders in democratic countries. Even if all adult citizens compose the selectorate, in clientelistic democracies, the size of the de facto winning coalition might be small if it is comprised of local intermediaries capable of mobilizing blocs of voters through the distribution of goodies before and after the election. Hence, in such systems, political incentives differ radically from other scenarios in which democracy relies less on patronage and vote buying.

\footnotetext{
${ }^{20}$ Naturally, it could be possible that the two effects are taking place at the same time: opposers are participating less and supporters are more involved. If that is the case and in the end the effect on turnout is null, we still need an explanation of why incumbent parties are winning more in 2011 in municipalities affected by floods and landslides.
} 
In terms of natural disasters, this description suggests that the political implications of the lethality of such events in clientelistic democracies, in many cases, could be closer to what happens in autocracies. The small size of the winning coalition implies that, even if many citizens are affected by the catastrophe, as long as the welfare of those whose support is essential to stay in power remains unaffected, incumbent parties have little reason to worry. In fact, given that the disaster generates a positive stock of aid, private goods, and cash for leaders, the event might increase political survival if incumbents use these resources strategically for buying votes. The evidence presented above provides support for this assertion, as parties governing places more affected by floods and landslides in Colombia were more likely to be reelected months after the disaster. Moreover, this paper demonstrates that allocation of food relief, a very clear form of distribution of private goods to potential supporters, increased the likelihood of reelection, while the same is not true for public goods in the form of infrastructure aid.

Naturally, the conclusions of this paper do not imply that aid should not be allocated after a disaster takes place, because politicians will use it strategically to obtain votes. The final message is that policies aimed to diminish clientelism will also reduce the incentives to strategically manipulate the utilization of disaster relief. In the meanwhile, alternative mechanisms can prevent this behavior if aid is managed and distributed by truly independent agencies and not by political organizations with clear electoral goals. In the context of climate change and global warming in which extreme climatological events are expected to become more frequent, it is important to understand what the political consequences of natural disasters are and what can be done to ameliorate the pervasive consequences of these events.

\section{Bibliography}

Abney, G. and Hill, L. (1966). Natural Disasters as a Political Variable: The Effect of a Hurricane on an Urban Election, American Political Science Review 60(4): 974-981.

Achen, C. and Bartels, L. (2004). Blind Retrospection Electoral Response to Drought, Flu, and Shark Attacks, Working Paper, Princeton University.

Anbarci, N., Escaleras, M. and Register, C. (2005). Earthquakes Fatalities: the Interaction of Nature and Political Economy, Journal of Public Economics 89(9-10): 1907-1933.

Ansolabehere, S., Snyder, J. and Stewart, C. (2000). Old Voters, New Voters, and the Personal Vote: 
Using Redistricting to Measure Incumbency Advantage, American Journal of Political Science 44: $17-44$

Brambor, T. and Ceneviva, R. (2011). Incumbency Advantage in Brazilian Mayoral Elections, Paper Prepared for the American Political Science Association Annual Meeting.

Brancati, D. (2007). Political Aftershocks: The Impacts of Earthquakes on Intrastate Conflict, Journal of Conflict Resolution 51(5): 715-743.

Bueno de Mesquita, B., Smith, A., Siverson, R. and Morrow, J. (2003). The Logic of Political Survival, MIT Press.

Chen, J. (2011). Voter Income and Mobilizing Effect of Distributive Benefits, Working Paper, University of Michigan.

Chen, J. (forthcoming). Distributive Spending, Voter Partisanship, and Political Participation: A Theory of Voter Turnout as Retrospective Evaluation, American Journal of Political Science .

Cohen, C. and Werker, E. (2008). The Political Economy of Natural Disasters, Journal of Conflict Resolution 52(6): 795-819.

Congleton, R. (2006). The Story of Katrina: New Orleans and the Political Economy of Catastrophe, Public Choice 127(1-2): 5-30.

DANE (2011). Informe final registro unico de damnificados por la emergencia invernal 2010-2011, Documento Oficial.

Eisensee, T. and Stromberg, D. (2007). News Drought, News Floods, and U.S. Disaster Relief, Quarterly Journal of Economics 122(2): 693-728.

Erikson, R. (1971). Electoral Accountability and the Control of Politicians: Selecting Good Types versus Sanctioning Poor Performance, Polity 3(395-405).

Escaleras, M., Anbarci, N. and Register, C. (2007). Public Sector Corruption and Major Earthquakes: A Potentially Deadly Interaction, Public Choice 132(1-2): 209-230.

Fair, C., Kuhn, P., Malhotra, N. and Shapiro, J. (2014). Economic Shocks and Civic Engagement: Evidence from the 2010-11 Pakistani Floods, Working Paper.

Ferejohn, J. (1986). Incumbent Performance and Electoral Control, Public Choice 30: 5-25.

Gallego, J. (2011). Civil Conflict and Voting Behavior: Evidence from Colombia, Working Paper, New York University.

Gallego, J. (2014). Self-enforcing clientelism, Journal of Theoretical Politics, doi: 10.1177/0951629814533840 .

Gelman, A. and King, G. (1990). Estimating Incumbency Advantage without Bias, American Journal 
of Political Science 34(1142-1164).

Gutierrez, F. (2007). Lo que el viento se llevo: los partidos politicos y la democracia en Colombia 1958-2002, Editorial Norma.

Hainmueller, J. and Lurz-Kern, H. (2008). Incumbency as a Source of Spillover Effects in Mixed Electoral Systems: Evidence from a Regression-Discontinuity Design, Electoral Studies 27(213227).

Healy, A. and Malhotra, N. (2009). Myopic Voters and Natural Disaster Policy, American Political Science Review 103(3): 387-406.

Horiuchi, Y. and Leigh, A. (2009). Estimating Incumbency Advantage: Evidence from Three Natural Experiments, Working Paper.

IDEAM (1998). Estudio Nacional del Agua, Instituto de Hidrologia, Meteorologia y Estudios Ambientales.

Kahn, M. (2005). The Death Tolls from Natural Disasters: The Role of Income, Geography, and Institutions, Review of Economics and Statistics 87(2): 271-284.

Katz, J. and King, G. (1999). A Statistical Model for Multiparty Electoral Data, American Political Science Review 93: 15-32.

Keefer, P., Neumayer, E. and Plumper, T. (2010). Earthquake Propensity and the Politics of Mortality Prevention, Policy Research Working Paper, World Bank.

Klasnja, M. (2012). Increasing Rents and Incumbency Disadvantage, Working Paper, New York University.

Linden, L. (2004). Are Incumbents Really Advantaged? The Preference for Non-Incumbents in Indian National Elections, Working Paper.

Miguel, E., Satyanath, S. and Sergenti, E. (2004). Economic Shocks and Civil Conflict: An Instrumental Variables Approach, Journal of Political Economy 112(4): 725-753.

Mustafa, D. (2003). Reinforcing Vulnerability? Disaster Relief, Recovery, and Response to the 2001 Flood in Rawalpindi, Pakistan, Environmental Hazards 5(3-4): 71-82.

Quiroz, A. and Smith, A. (2010). Surviving Disasters, Working Paper, New York University.

Raschky, P. and Schwindt, M. (2009). Aid, Natural Disasters, and the Samaritan's Dilemma, Policy Research Working Paper 4952, World Bank.

Sanchez, A. (2011). Despues de la inundacion, Documento de trabajo sobre economia regional No. 150, Banco de la Republica.

Smith, A. and Bueno de Mesquita, B. (2012). Contingent Prize Allocation and Pivotal Voting, 
British Journal of Political Science 42(2): 371-392.

Stromberg, D. (2007). Natural Disasters, Economic Development, and Humanitarian Aid, Journal of Economic Perspectives 21(3): 199-222.

Titiunik, R. (2009). Incumbency Advantage in Brazil: Evidence from Municipal Mayor Elections, Working Paper.

Toya, H. and Skidmore, M. (2007). Economic Development and the Impacts of Natural Disasters, Economics Letters 94(1): 20-25.

Uppal, Y. (2009). Estimating Incumbency Effects in U.S. State Legislatures: A Quasi-Experimental Study, Public Choice 138: 9-27. 
Table 1: Victimization and Reelection: DID Estimates

\begin{tabular}{|c|c|c|c|c|}
\hline & $\begin{array}{c}(1) \\
\text { Reelection }\end{array}$ & $\begin{array}{c}(2) \\
\text { Reelection }\end{array}$ & $\begin{array}{c}(3) \\
\text { Reelection }\end{array}$ & $\begin{array}{c}(4) \\
\text { Reelection }\end{array}$ \\
\hline Victims $\times$ Post2010 & $\begin{array}{c}0.225 * * * \\
(0.0767)\end{array}$ & $\begin{array}{l}0.212^{* * *} \\
(0.0770)\end{array}$ & $\begin{array}{c}0.163^{*} \\
(0.0840)\end{array}$ & $\begin{array}{c}0.151^{*} \\
(0.0879)\end{array}$ \\
\hline Post2010 & $\begin{array}{l}-0.0220 \\
(0.0186)\end{array}$ & $\begin{array}{l}-0.0155 \\
(0.0192)\end{array}$ & $\begin{array}{c}-0.101 \\
(0.0689)\end{array}$ & $\begin{array}{l}-0.0992 \\
(0.0727)\end{array}$ \\
\hline Population $\times$ Post 2010 & & $\begin{array}{l}-8.68 \mathrm{e}-08 \\
(5.62 \mathrm{e}-08)\end{array}$ & $\begin{array}{l}-8.68 \mathrm{e}-08 \\
(5.38 \mathrm{e}-08)\end{array}$ & $\begin{array}{l}-8.64 \mathrm{e}-08 \\
(5.44 \mathrm{e}-08)\end{array}$ \\
\hline Popdensity $\times$ Post 2010 & & $\begin{array}{l}-0.0000126 \\
(0.0000402)\end{array}$ & $\begin{array}{l}-0.0000122 \\
(0.0000400)\end{array}$ & $\begin{array}{l}-0.0000113 \\
(0.0000411)\end{array}$ \\
\hline Temperature $\times$ Post2010 & & & $\begin{array}{c}0.00407 \\
(0.00317)\end{array}$ & $\begin{array}{c}0.00368 \\
(0.00335)\end{array}$ \\
\hline Poverty $\times$ Post 2010 & & & & $\begin{array}{c}0.000129 \\
(0.000928)\end{array}$ \\
\hline Constant & $\begin{array}{l}0.160^{* * *} \\
(0.00755)\end{array}$ & $\begin{array}{l}0.160^{* * * *} \\
(0.00754)\end{array}$ & $\begin{array}{l}0.161^{* * * *} \\
(0.00761)\end{array}$ & $\begin{array}{l}0.161^{* * * *} \\
(0.00762)\end{array}$ \\
\hline Fixed Effects & $\mathrm{Y}$ & $\mathrm{Y}$ & $\mathrm{Y}$ & $\mathrm{Y}$ \\
\hline Clustered St. Errors & $\begin{array}{c}\mathrm{Y} \\
2200\end{array}$ & $\begin{array}{c}Y \\
2196\end{array}$ & $\begin{array}{c}\mathrm{Y} \\
2144\end{array}$ & $\begin{array}{c}\mathrm{Y} \\
2134\end{array}$ \\
\hline
\end{tabular}

Notes: Standard errors clustered at the municipality level are shown in parentheses. Election years in the sample are 2007 and 2011. Reelection is a dummy variable that equals 1 if the incumbent party wins the election. Victims is the number of victims per capita. Post2010 equals 1 for 2011 observations and 0 otherwise. OLS Fixed Effects estimation is used in every specification. ${ }^{*}$ is significant at the $10 \%$ level, ${ }^{* *}$ is significant at the $5 \%$ level, ${ }^{* * *}$ is significant at the $1 \%$ level. 
Table 2: Victimization and Reelection: Instrumental Variable Estimates

\begin{tabular}{|c|c|c|c|c|}
\hline \multicolumn{5}{|c|}{ Second Stage } \\
\hline \multirow{3}{*}{ Victims $\times$ Post 2010} & Reelection & Reelection & Reelection & Reelection \\
\hline & $0.449 * *$ & $0.441^{* *}$ & $0.424^{*}$ & $0.453^{*}$ \\
\hline & $(0.208)$ & $(0.209)$ & $(0.241)$ & $(0.272)$ \\
\hline \multirow[t]{2}{*}{ Post2010 } & $-0.0613^{*}$ & -0.0556 & -0.0802 & -0.0520 \\
\hline & $(0.0345)$ & $(0.0357)$ & $(0.0706)$ & $(0.0833)$ \\
\hline \multirow{2}{*}{ Population $\times$ Post 2010} & & $-7.88 \mathrm{e}-08$ & $-7.91 \mathrm{e}-08$ & $-8.17 \mathrm{e}-08$ \\
\hline & & $(6.09 \mathrm{e}-08)$ & $(6.01 \mathrm{e}-08)$ & $(5.73 \mathrm{e}-08)$ \\
\hline \multirow[t]{2}{*}{ Popdensity $\times$ Post 2010} & & -0.000007 & -0.000007 & -0.00001 \\
\hline & & $(0.00004)$ & $(0.00004)$ & $(0.00004)$ \\
\hline \multirow[t]{2}{*}{ Temperature $\times$ Post 2010} & & & 0.00123 & 0.00198 \\
\hline & & & $(0.00392)$ & $(0.00362)$ \\
\hline \multirow[t]{4}{*}{ Poverty $\times$ Post 2010} & & & & -0.000910 \\
\hline & & & & $(0.00132)$ \\
\hline & Firs & Stage & & \\
\hline & Vic $\times$ P2010 & Vic $\times$ P2010 & Vic $\times$ P2010 & Vic $\times$ P2010 \\
\hline \multirow[t]{2}{*}{ Water $\times$ Post2010 } & $0.024^{* * *}$ & $0.024^{* * *}$ & $0.022^{* * *}$ & $0.019 * * *$ \\
\hline & $(0.003)$ & $(0.003)$ & $(0.003)$ & $(0.003)$ \\
\hline \multirow[t]{2}{*}{ Post2010 } & $0.132^{* * *}$ & $0.136^{* * *}$ & -0.018 & $-0.103^{* * *}$ \\
\hline & $(0.006)$ & $(0.006)$ & $(0.023)$ & $(0.024)$ \\
\hline \multirow[t]{2}{*}{ Population $\times$ Post 2010} & & $-2.29 \mathrm{e}-08$ & $-2.25 \mathrm{e}-08$ & $-1.13 \mathrm{e}-08$ \\
\hline & & $(1.54 \mathrm{e}-08)$ & $(2.15 \mathrm{e}-08)$ & $(1.06 \mathrm{e}-08)$ \\
\hline \multirow[t]{2}{*}{ Popdensity $\times$ Post 2010} & & $-0.00002^{* * *}$ & $-0.00002^{* * *}$ & $7.39 \mathrm{e}-07$ \\
\hline & & $(7.03 \mathrm{e}-06)$ & $(7.00 \mathrm{e}-06)$ & $(2.29 \mathrm{e}-06)$ \\
\hline \multirow[t]{2}{*}{ Temperature $\times$ Post2010 } & & & $0.007 * * *$ & $0.003^{* * *}$ \\
\hline & & & $(0.001)$ & $(0.001)$ \\
\hline \multirow[t]{2}{*}{ Poverty $\times$ Post 2010} & & & & $0.003^{* * *}$ \\
\hline & & & & $(0.0003)$ \\
\hline Fixed Effects & $\mathrm{Y}$ & $\mathrm{Y}$ & $\mathrm{Y}$ & $\mathrm{Y}$ \\
\hline Clustered St. Errors & $\mathrm{Y}$ & $\mathrm{Y}$ & $\mathrm{Y}$ & $\mathrm{Y}$ \\
\hline First Stage F-Stat & 342.15 & 171.85 & 143.62 & 137.40 \\
\hline KP Wald F-Stat & 70.28 & 69.32 & 51.01 & 40.34 \\
\hline$N$ & 2136 & 2134 & 2128 & 2122 \\
\hline
\end{tabular}

Notes: Standard errors clustered at the municipality level are shown in parentheses. Election years in the sample are 2007 and 2011. Reelection is a dummy variable that equals 1 if the incumbent party wins the election. Victims is the number of victims per capita. Post2010 equals 1 for 2011 observations and 0 otherwise. IV Fixed Effects estimation is used in every specification. ${ }^{*}$ is significant at the $10 \%$ level, ${ }^{* *}$ is significant at the $5 \%$ level, ${ }^{* * *}$ is significant at the $1 \%$ level. 
Table 3: Testing the Mechanism: Humanitarian Aid, Electoral Irregularities, and Reelection

\begin{tabular}{|c|c|c|c|c|c|c|c|c|}
\hline & $\begin{array}{c}\text { (1) } \\
\text { Reelection }\end{array}$ & $\begin{array}{c}\text { (2) } \\
\text { Reelection }\end{array}$ & $\begin{array}{c}(3) \\
\text { Reelection }\end{array}$ & $\begin{array}{c}\text { (4) } \\
\text { Reelection }\end{array}$ & $\begin{array}{c}(5) \\
\text { Reelection }\end{array}$ & $\begin{array}{c}\text { (6) } \\
\text { Reelection }\end{array}$ & $\begin{array}{c}(7) \\
\text { Reelection }\end{array}$ & $\begin{array}{c}\text { (8) } \\
\text { Reelection }\end{array}$ \\
\hline Food & $\begin{array}{c}2.574^{* * *} \\
(0.898)\end{array}$ & $\begin{array}{c}2.613^{* * *} \\
(0.899)\end{array}$ & $\begin{array}{l}2.510^{* *} \\
(1.017)\end{array}$ & $\begin{array}{l}1.831^{*} \\
(1.065)\end{array}$ & & & & \\
\hline Infrastructure & $\begin{array}{c}-3.99 \mathrm{e}-08 \\
(0.0000002)\end{array}$ & $\begin{array}{c}-2.70 \mathrm{e}-08 \\
(0.0000002)\end{array}$ & $\begin{array}{c}-1.54 \mathrm{e}-08 \\
(0.0000002)\end{array}$ & $\begin{array}{c}-6.66 \mathrm{e}-09 \\
(0.0000002)\end{array}$ & & & & \\
\hline Irregularities & & & & & $\begin{array}{c}0.280^{* *} \\
(0.114)\end{array}$ & $\begin{array}{c}0.277^{* *} \\
(0.115)\end{array}$ & $\begin{array}{c}0.300^{* *} \\
(0.119)\end{array}$ & $\begin{array}{c}0.301^{* *} \\
(0.120)\end{array}$ \\
\hline Population & & $\begin{array}{c}8.16 \mathrm{e}-08 \\
(0.0000004)\end{array}$ & $\begin{array}{c}0.0000001 \\
(0.0000004)\end{array}$ & $\begin{array}{c}0.0000002 \\
(0.0000004)\end{array}$ & & $\begin{array}{l}-0.000000141 \\
(0.000000308)\end{array}$ & $\begin{array}{l}-0.000000123 \\
(0.000000286)\end{array}$ & $\begin{array}{c}-7.65 \mathrm{e}-08 \\
(0.000000252)\end{array}$ \\
\hline Popdensity & & $\begin{array}{c}0.00003 \\
(0.00008)\end{array}$ & $\begin{array}{c}0.00002 \\
(0.00008)\end{array}$ & $\begin{array}{c}0.00005 \\
(0.00008)\end{array}$ & & $\begin{array}{c}0.0000329 \\
(0.0000701)\end{array}$ & $\begin{array}{c}0.0000332 \\
(0.0000696)\end{array}$ & $\begin{array}{c}0.0000662 \\
(0.0000681)\end{array}$ \\
\hline Temperature & & & $\begin{array}{l}-0.00905 \\
(0.00980)\end{array}$ & $\begin{array}{l}-0.0152 \\
(0.0103)\end{array}$ & & & $\begin{array}{l}-0.00788 \\
(0.00926)\end{array}$ & $\begin{array}{l}-0.0152 \\
(0.0100)\end{array}$ \\
\hline Poverty & & & & $\begin{array}{c}0.00587^{* *} \\
(0.00278)\end{array}$ & & & & $\begin{array}{c}0.00609 * * \\
(0.00262)\end{array}$ \\
\hline Constant & $\begin{array}{c}-0.987^{* * *} \\
(0.0548)\end{array}$ & $\begin{array}{c}-0.999 * * * \\
(0.0573)\end{array}$ & $\begin{array}{c}-0.823^{* * *} \\
(0.211)\end{array}$ & $\begin{array}{c}-1.009 * * * \\
(0.229)\end{array}$ & $\begin{array}{c}-1.008^{* * *} \\
(0.0491)\end{array}$ & $\begin{array}{c}-1.004^{* * *} \\
(0.0505)\end{array}$ & $\begin{array}{c}-0.859 * * * \\
(0.202)\end{array}$ & $\begin{array}{c}-1.039 * * * \\
(0.215)\end{array}$ \\
\hline$N$ & 1057 & 1055 & 1029 & 1025 & 1131 & 1113 & 1086 & 1067 \\
\hline
\end{tabular}

Notes: Standard errors are shown in parentheses. Cross-sectional estimates for 2011 are reported. Reelection is a dummy variable that equals 1 if the incumbent party wins the election. Food is the number grocery and hygiene kits distributed per capita. Infrastructure is the amount of Colombian pesos per capita disbursed for infrastructure projects. Irregularities is a dummy variable that equals 1 if the municipality is being investigated for vote buying irregularities. Probit regression is used in every specification. * is significant at the $10 \%$ level, ** is significant at the $5 \%$ level, $* * *$ is significant at the $1 \%$ level. 
Table 4: Placebo Test (Post Election Victims and Reelection)

\begin{tabular}{|c|c|c|c|c|c|c|c|c|}
\hline & $\begin{array}{c}(1) \\
\text { OLS FE }\end{array}$ & $\begin{array}{c}(2) \\
\text { OLS FE }\end{array}$ & $\begin{array}{c}(3) \\
\text { OLS FE }\end{array}$ & $\begin{array}{c}(4) \\
\text { OLS FE }\end{array}$ & $\begin{array}{l}(5) \\
\text { IV }\end{array}$ & $\begin{array}{l}(6) \\
\text { IV }\end{array}$ & $\begin{array}{l}(7) \\
\text { IV }\end{array}$ & $\begin{array}{l}(8) \\
\text { IV }\end{array}$ \\
\hline VictimsAfter $\times$ Post 2010 & $\begin{array}{c}0.0532 \\
(0.0840)\end{array}$ & $\begin{array}{c}0.0505 \\
(0.0841)\end{array}$ & $\begin{array}{c}-0.0326 \\
(0.112)\end{array}$ & $\begin{array}{l}-0.154^{*} \\
(0.0866)\end{array}$ & $\begin{array}{c}7.961 \\
(9.933)\end{array}$ & $\begin{array}{c}7.984 \\
(10.21)\end{array}$ & $\begin{array}{l}-30.50 \\
(143.9)\end{array}$ & $\begin{array}{l}-8.983 \\
(13.39)\end{array}$ \\
\hline Population $\times$ Post 2010 & & $\begin{array}{c}-9.28 \mathrm{e}-08^{*} \\
(5.30 \mathrm{e}-08)\end{array}$ & $\begin{array}{c}-9.14 \mathrm{e}-08^{*} \\
(5.03 \mathrm{e}-08)\end{array}$ & $\begin{array}{c}-8.88 \mathrm{e}-08^{*} \\
(5.28 \mathrm{e}-08)\end{array}$ & & $\begin{array}{c}-4.44 \mathrm{e}-08 \\
(0.000000109)\end{array}$ & $\begin{array}{l}-0.000000260 \\
(0.000000826)\end{array}$ & $\begin{array}{c}-0.000000104 \\
(7.11 \mathrm{e}-08)\end{array}$ \\
\hline Popdensity $\times$ Post 2010 & & $\begin{array}{l}-0.0000170 \\
(0.0000394)\end{array}$ & $\begin{array}{l}-0.0000155 \\
(0.0000392)\end{array}$ & $\begin{array}{l}-0.0000105 \\
(0.0000411)\end{array}$ & & $\begin{array}{c}0.0000206 \\
(0.0000708)\end{array}$ & $\begin{array}{l}-0.000140 \\
(0.000609)\end{array}$ & $\begin{array}{c}0.0000130 \\
(0.0000621)\end{array}$ \\
\hline Temperature $\times$ Post 2010 & & & $\begin{array}{l}0.00583^{*} \\
(0.00309)\end{array}$ & $\begin{array}{c}0.00485 \\
(0.00331)\end{array}$ & & & $\begin{array}{c}0.133 \\
(0.600)\end{array}$ & $\begin{array}{c}0.0258 \\
(0.0323)\end{array}$ \\
\hline Poverty $\times$ Post 2010 & & & & $\begin{array}{c}0.000802 \\
(0.000903)\end{array}$ & & & & $\begin{array}{l}0.00946 \\
(0.0129)\end{array}$ \\
\hline Post2010 & $\begin{array}{c}0.0105 \\
(0.0155)\end{array}$ & $\begin{array}{c}0.0160 \\
(0.0161)\end{array}$ & $\begin{array}{c}-0.113 \\
(0.0688)\end{array}$ & $\begin{array}{l}-0.133^{*} \\
(0.0722)\end{array}$ & $\begin{array}{l}-0.285 \\
(0.357)\end{array}$ & $\begin{array}{l}-0.288 \\
(0.377)\end{array}$ & $\begin{array}{l}-1.709 \\
(7.562)\end{array}$ & $\begin{array}{l}-0.749 \\
(0.924)\end{array}$ \\
\hline Constant & $\begin{array}{l}0.160 * * * \\
(0.00758)\end{array}$ & $\begin{array}{l}0.160^{* * *} \\
(0.00757)\end{array}$ & $\begin{array}{l}0.161^{* * *} \\
(0.00762)\end{array}$ & $\begin{array}{l}0.161^{* * *} \\
(0.00762)\end{array}$ & & & & \\
\hline Fixed Effects & $\mathrm{Y}$ & $\mathrm{Y}$ & $\mathrm{Y}$ & $\mathrm{Y}$ & $\mathrm{Y}$ & $\mathrm{Y}$ & $\mathrm{Y}$ & $\mathrm{Y}$ \\
\hline Clustered St. Errors & $\mathrm{Y}$ & $\mathrm{Y}$ & $\mathrm{Y}$ & $\mathrm{Y}$ & $\mathrm{Y}$ & $\mathrm{Y}$ & $\mathrm{Y}$ & $\mathrm{Y}$ \\
\hline$N$ & 2200 & 2196 & 2144 & 2134 & 2136 & 2134 & 2128 & 2122 \\
\hline
\end{tabular}

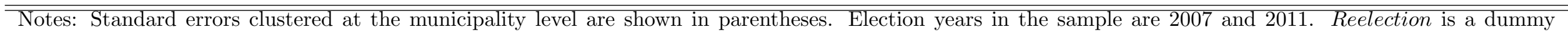
variable that equals 1 if the incumbent party wins the election. Victims After is the number of victims per capita during the second rainy season. Post2010 equals 1 for 2011 observations and 0 otherwise. OLS Fixed Effects estimation is used in columns 1-4. IV Fixed Effects estimation is used in columns 1-4. * is significant at the $10 \%$ level, $* *$ is significant at the $5 \%$ level, $* * *$ is significant at the $1 \%$ level. 
Table 5: Alternative Mechanisms: Ruling Out Accountability and Political Engagement

\begin{tabular}{|c|c|c|c|c|c|c|c|c|}
\hline & $\begin{array}{c}(1) \\
\text { Reelection }\end{array}$ & $\begin{array}{c}(2) \\
\text { Reelection }\end{array}$ & $\begin{array}{c}(3) \\
\text { Reelection }\end{array}$ & $\begin{array}{c}(4) \\
\text { Reelection }\end{array}$ & $\begin{array}{c}(5) \\
\text { Turnout }\end{array}$ & $\begin{array}{c}(6) \\
\text { Turnout }\end{array}$ & $\begin{array}{c}(7) \\
\text { Turnout }\end{array}$ & $\begin{array}{c}(8) \\
\text { Turnout }\end{array}$ \\
\hline Delays & $\begin{array}{l}-0.140 \\
(0.115)\end{array}$ & $\begin{array}{l}-0.133 \\
(0.115)\end{array}$ & $\begin{array}{l}-0.139 \\
(0.118)\end{array}$ & $\begin{array}{l}-0.141 \\
(0.119)\end{array}$ & & & & \\
\hline Victims & & & & & $\begin{array}{l}-0.0979 \\
(1.368)\end{array}$ & $\begin{array}{l}-1.012 \\
(1.340)\end{array}$ & $\begin{array}{c}2.160 \\
(1.335)\end{array}$ & $\begin{array}{c}1.390 \\
(1.412)\end{array}$ \\
\hline Population & & $\begin{array}{l}-0.0000001 \\
(0.0000003)\end{array}$ & $\begin{array}{l}-0.0000001 \\
(0.0000003)\end{array}$ & $\begin{array}{c}-6.77 \mathrm{e}-08 \\
(0.0000003)\end{array}$ & & $\begin{array}{c}-0.00000455^{* * *} \\
(0.00000118)\end{array}$ & $\begin{array}{c}-0.00000449 * * * \\
(0.00000113)\end{array}$ & $\begin{array}{c}-0.00000441^{* * *} \\
(0.00000113)\end{array}$ \\
\hline Popdensity & & $\begin{array}{c}0.00004 \\
(0.00007)\end{array}$ & $\begin{array}{c}0.00004 \\
(0.00007)\end{array}$ & $\begin{array}{c}0.00007 \\
(0.00007)\end{array}$ & & $\begin{array}{c}-0.00183^{* * *} \\
(0.000428)\end{array}$ & $\begin{array}{c}-0.00183^{* * *} \\
(0.000410)\end{array}$ & $\begin{array}{c}-0.00170 * * * \\
(0.000418)\end{array}$ \\
\hline Temperature & & & $\begin{array}{l}-0.00181 \\
(0.00912)\end{array}$ & $\begin{array}{c}-0.0102 \\
(0.00981)\end{array}$ & & & $\begin{array}{c}-0.520 * * * \\
(0.0527)\end{array}$ & $\begin{array}{c}-0.549 * * * \\
(0.0549)\end{array}$ \\
\hline Poverty & & & & $\begin{array}{c}0.00593 * * \\
(0.00261)\end{array}$ & & & & $\begin{array}{c}0.0249 \\
(0.0154)\end{array}$ \\
\hline Constant & $\begin{array}{c}-0.919 * * * \\
(0.0494)\end{array}$ & $\begin{array}{c}-0.922^{* * *} \\
(0.0508)\end{array}$ & $\begin{array}{c}-0.903^{* * *} \\
(0.202)\end{array}$ & $\begin{array}{c}-1.058 * * * \\
(0.215)\end{array}$ & $\begin{array}{c}66.93^{* * *} \\
(0.338)\end{array}$ & $\begin{array}{c}67.54^{* * *} \\
(0.340)\end{array}$ & $\begin{array}{c}78.26^{* * *} \\
(1.133)\end{array}$ & $\begin{array}{c}77.66^{* * *} \\
(1.211)\end{array}$ \\
\hline$N$ & 1103 & 1098 & 1072 & 1067 & 1067 & 1067 & 1065 & 1062 \\
\hline
\end{tabular}

Notes: Standard errors are shown in parentheses. Cross-sectional estimates for 2011 are reported. Reelection is a dummy variable that equals 1 if the incumbent party wins the election. Turnout is the rate of political participation in the 2011 Mayoral election. Delays is a dummy variable that equals 1 if the municipality is being investigated for delays in infrastructure projects. Victims is the number of victims per capita. Probit regression is used in columns 1-4. OLS regression is used in columns $5-8$. * is significant at the $10 \%$ level, $* *$ is significant at the $5 \%$ level, $* * *$ is significant at the $1 \%$ level. 
Figure 1: Spatial Distribution of Exposure to the Disaster (No. of Victims)

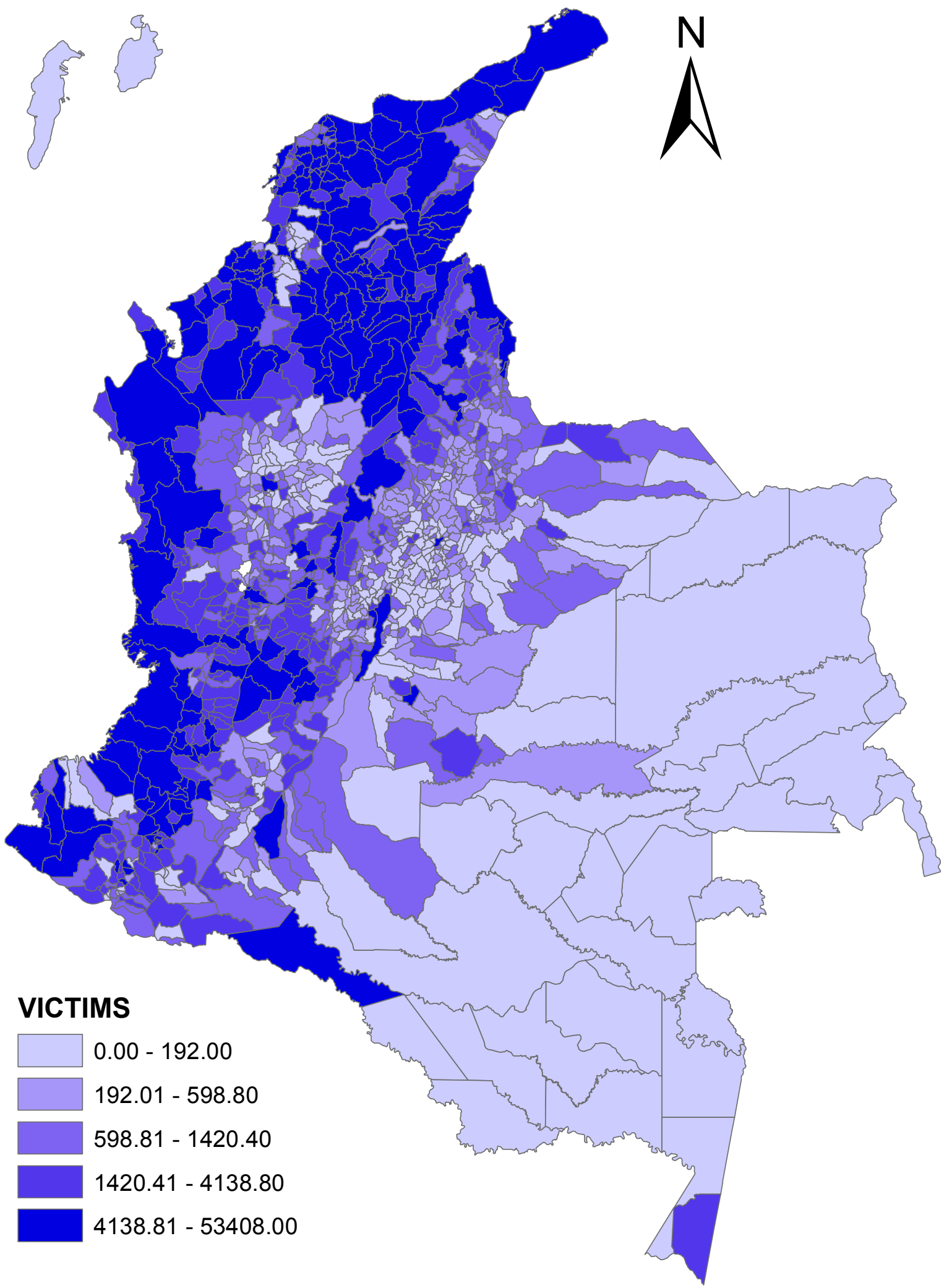


Figure 2: Victimization and Reelection

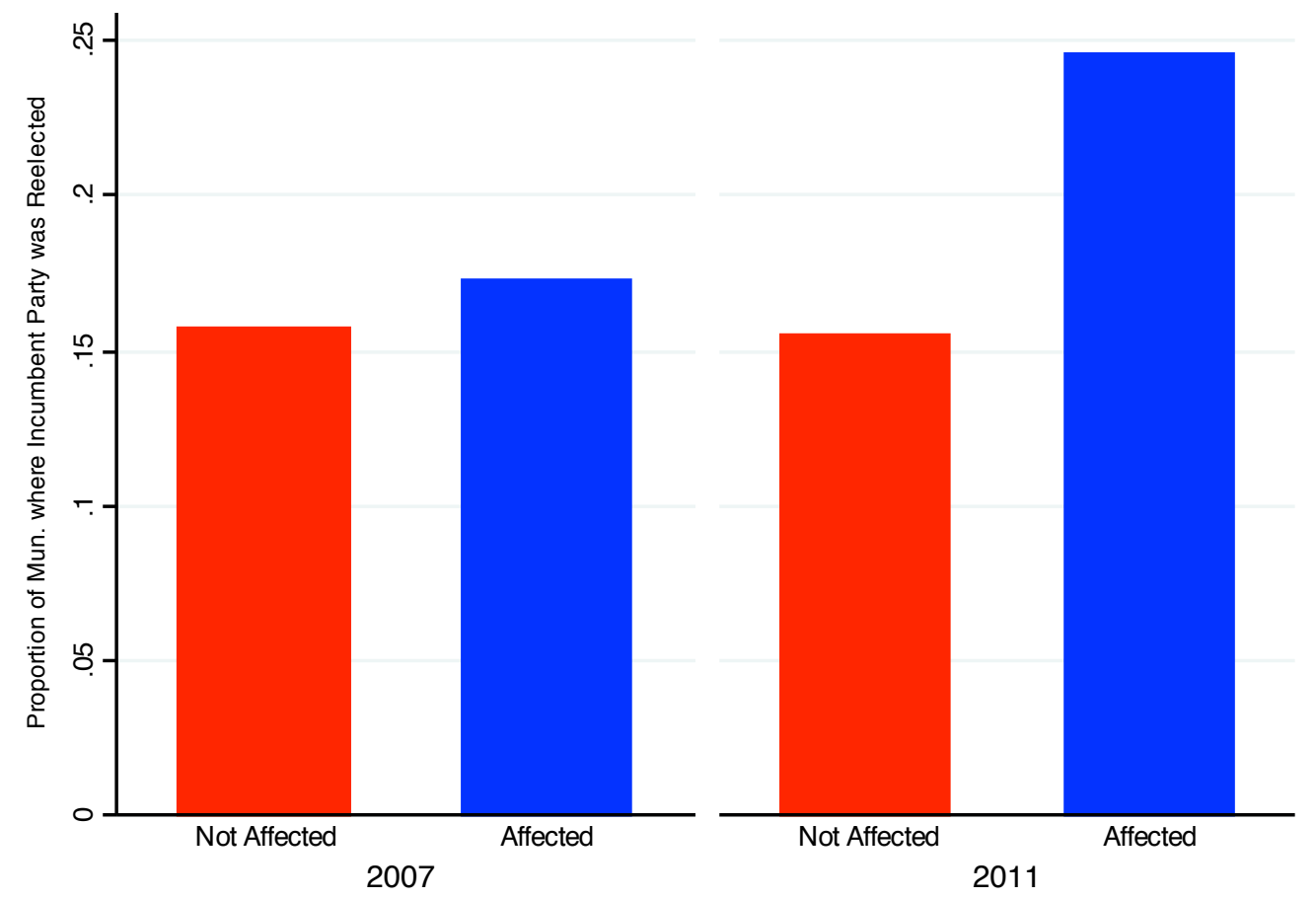




\section{Natural Disasters and Clientelism: the Case of Floods and Landslides in Colombia}

February 10, 2015

\section{On-Line Appendix}

\subsection{Extreme Rainfall and Reelection}

In order to understand the correlation between extreme precipitation and levels of victimization, Figure A1 presents a scatter plot and fits a linear regression of extreme rainfall on the rate of victims per capita. The graph suggests that the first path of causation is correct: municipalities that experienced abnormal days of extreme rainfall between October of 2010 and March of 2011, tend to have higher rates of victims per capita.

According to the mechanism proposed in this paper, the second path of causation would suggest that if extreme rainfall causes more victims, and more victims increase the likelihood of reelection, in the group of municipalities heavily affected by rainfall there should be a higher increase in the proportion of elections won by the incumbent party after the disaster, compared to municipalities not affected. Figure A2 reveals that this intuition is correct. In this case affected municipalities are those that experienced a maximum level of rainfall in 24 hours above the 80th percentile. ${ }^{1}$ Clearly, comparing 2007 to 2011, in non-affected municipalities there is a slight decrease in the proportion of places where reelection was achieved. The pattern is completely different for affected municipalities: as compared to 2007, there is a significant increase, suggesting that events of extreme precipitation favored incumbent parties in these places.

\footnotetext{
${ }^{1}$ As usual, the result is robust to other thresholds.
} 
Figure A1: Correlation Between Extreme Rainfall and Victims per Capita

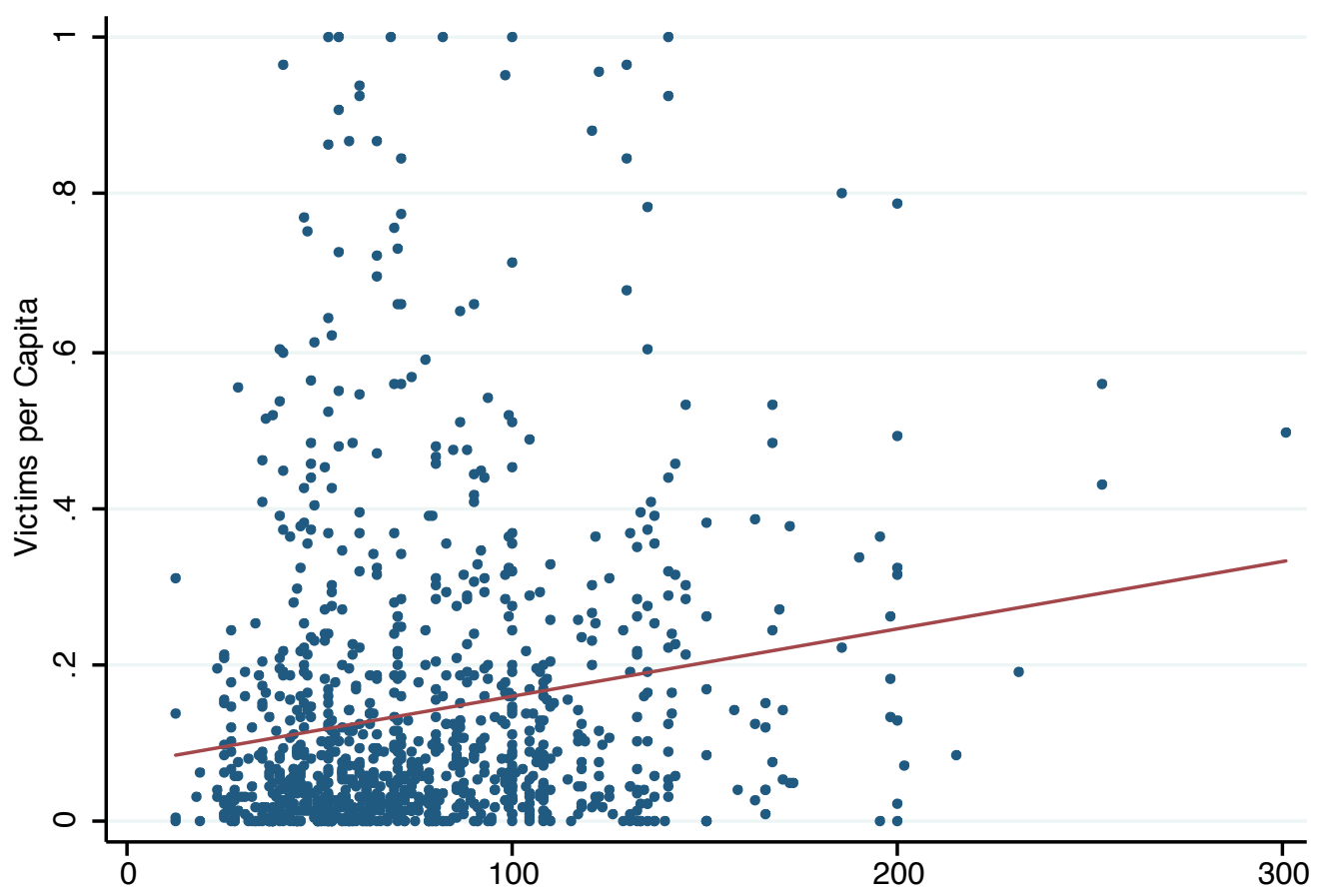

Max Level of Rainfall in 24hrs Between Oct. 2010 and Mar. 2011

Figure A2: Extreme Rainfall and Reelection

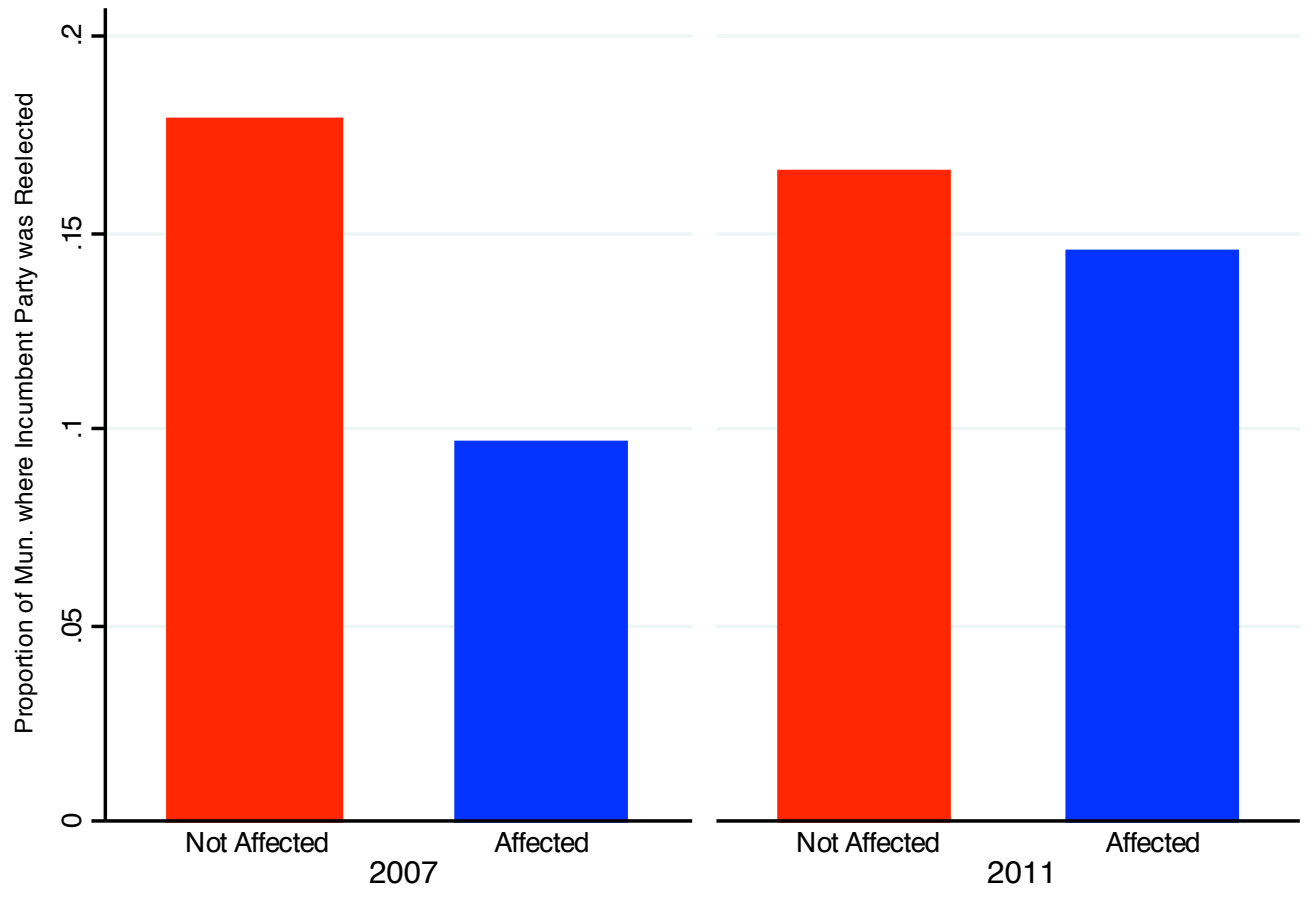


Table A1 corroborates through linear regressions the results presented above. Columns 1-4 of this table report alternative estimations of equation 2 in the main paper. As before, all the specifications include fixed and time effects, and standard errors are clustered at the municipality level. Column 1 does not include other controls, column 2 adds 2007 levels of population and population density interacted with the time dummy, column 3 includes temperature, while column 4 adds poverty to the analysis. In every case the coefficient of interest, $\gamma$, is positive and significant, suggesting that in 2011, compared to 2007, municipalities that experienced higher maximum levels of precipitation in 24 hours also exhibited a higher increase in the probability of reelecting the incumbent party. Therefore, the result presented above is robust to this alternative -and plausibly more exogenous- measure of exposure to the disaster.

Table A1: Extreme Rainfall and Reelection: DID Estimates

\begin{tabular}{|c|c|c|c|c|}
\hline & $\begin{array}{c}(1) \\
\text { Reelection }\end{array}$ & $\begin{array}{c}(2) \\
\text { Reelection }\end{array}$ & $\begin{array}{c}(3) \\
\text { Reelection }\end{array}$ & $\begin{array}{c}(4) \\
\text { Reelection }\end{array}$ \\
\hline Rainfall $\times$ Post 2010 & $\begin{array}{c}0.000965^{* *} \\
(0.000390)\end{array}$ & $\begin{array}{c}0.000952^{* *} \\
(0.000389)\end{array}$ & $\begin{array}{c}0.000849 * * \\
(0.000419)\end{array}$ & $\begin{array}{l}0.000764^{*} \\
(0.000424)\end{array}$ \\
\hline Post2010 & $\begin{array}{c}-0.0753^{* *} \\
(0.0346)\end{array}$ & $\begin{array}{c}-0.0683^{* *} \\
(0.0348)\end{array}$ & $\begin{array}{c}-0.107 \\
(0.0698)\end{array}$ & $\begin{array}{c}-0.116 \\
(0.0729)\end{array}$ \\
\hline Population $\times$ Post 2010 & & $\begin{array}{c}-8.82 \mathrm{e}-08^{*} \\
(5.14 \mathrm{e}-08)\end{array}$ & $\begin{array}{c}-8.83 \mathrm{e}-08^{*} \\
(5.05 \mathrm{e}-08)\end{array}$ & $\begin{array}{l}-8.63 \mathrm{e}-08 \\
(5.26 \mathrm{e}-08)\end{array}$ \\
\hline Popdensity $\times$ Post 2010 & & $\begin{array}{l}-0.0000147 \\
(0.0000393)\end{array}$ & $\begin{array}{l}-0.0000145 \\
(0.0000392)\end{array}$ & $\begin{array}{c}-0.0000111 \\
(0.0000409)\end{array}$ \\
\hline Temperature $\times$ Post 2010 & & & $\begin{array}{c}0.00215 \\
(0.00336)\end{array}$ & $\begin{array}{c}0.00153 \\
(0.00354)\end{array}$ \\
\hline Poverty $\times$ Post 2010 & & & & $\begin{array}{c}0.000532 \\
(0.000930)\end{array}$ \\
\hline Constant & $\begin{array}{c}0.165^{* * *} \\
(0.00773)\end{array}$ & $\begin{array}{c}0.165^{* * *} \\
(0.00772)\end{array}$ & $\begin{array}{l}0.165^{* * *} \\
(0.00772)\end{array}$ & $\begin{array}{l}0.164^{* * *} \\
(0.00774)\end{array}$ \\
\hline Fixed Effects & $\mathrm{Y}$ & $\mathrm{Y}$ & $\mathrm{Y}$ & $\mathrm{Y}$ \\
\hline Clustered St. Errors & Y & Y & Y & Y \\
\hline$N$ & 2078 & 2078 & 2078 & 2070 \\
\hline
\end{tabular}

Standard errors in parentheses

${ }^{*} p<0.10,{ }^{* *} p<0.05,{ }^{* * *} p<0.01$ 


\subsection{Disasters and Agricultural Output}

A major concern posed by the empirical strategy used above is that disasters such as floods and landslides might affect agricultural production, and consequently generate income shocks that can alter political preferences. Although it is not completely clear why the positive change on incumbent support would be larger in regions heavily affected by these shocks, such effects might be confounding and biasing the results reported above. In order to rule out this source of potential bias, an extended version of (1) in the text is estimated:

$$
\begin{aligned}
\text { Reelection }_{i t} & =\alpha_{i}+\beta_{t}+\left(\text { Victims }_{i} \times{\text { Post } \left.2010_{t}\right) \delta}\right. \\
& +\left(\text { Planted }_{i} \times \text { Post } 2010\right) \kappa+\mathbf{X}_{i t} \phi+\varepsilon_{i t}
\end{aligned}
$$

where Planted $_{i}$ refers to the total per capita agricultural planted area in municipality $i$, measured in hectares for 2008 by the Ministry of Agriculture. An alternative specification uses

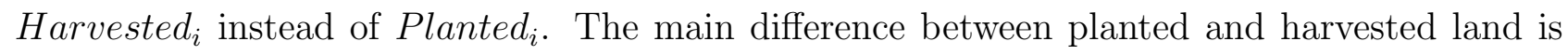
that the former includes area that is not productive yet - growth stage, while the latter only includes productive land.

Alternative specifications for the IV approach are also estimated. The extended version of the first stage is

$$
\begin{aligned}
\text { Victims }_{i} \times \text { Post } 2010 & =\alpha_{i}+\beta_{t}+\left(\text { Water }_{i} \times \text { Post }_{2010_{t}}\right) \eta \\
& +\left(\text { Planted }_{i} \times \text { Post } 2010\right) \kappa+\mathbf{X}_{i t} \phi+\omega_{i t}
\end{aligned}
$$

While the second stage is given by:

$$
\begin{aligned}
& \text { Reelection }_{i t}=\alpha_{i}+\beta_{t}+\left(\text { Victim }_{s_{i} \times P} \text { ost } 2010_{t}\right) \rho \\
& \text { (Planted } \left._{i} \times \text { Post } 2010\right)_{\zeta}+\mathbf{X}_{i t} \phi+\varepsilon_{i t}
\end{aligned}
$$

where all the variables are defined as above. Table A2 reports the results of these specifications. Columns 1-4 present he DID specifications, while columns 5-8 report the results of the IV approach. In every case, even after controlling for the total planted (harvested) land, the 
effect of victimization on the probability of reelecting the incumbent party remains positive and significant. Hence, the basic result that in 2011 the increase in the probability of reelection is higher in municipalities more affected by the disaster is robust even when controlling for shocks that might affect agricultural production. 
Table A2: Victimization and Reelection Controlling for Planted and Harvested Land

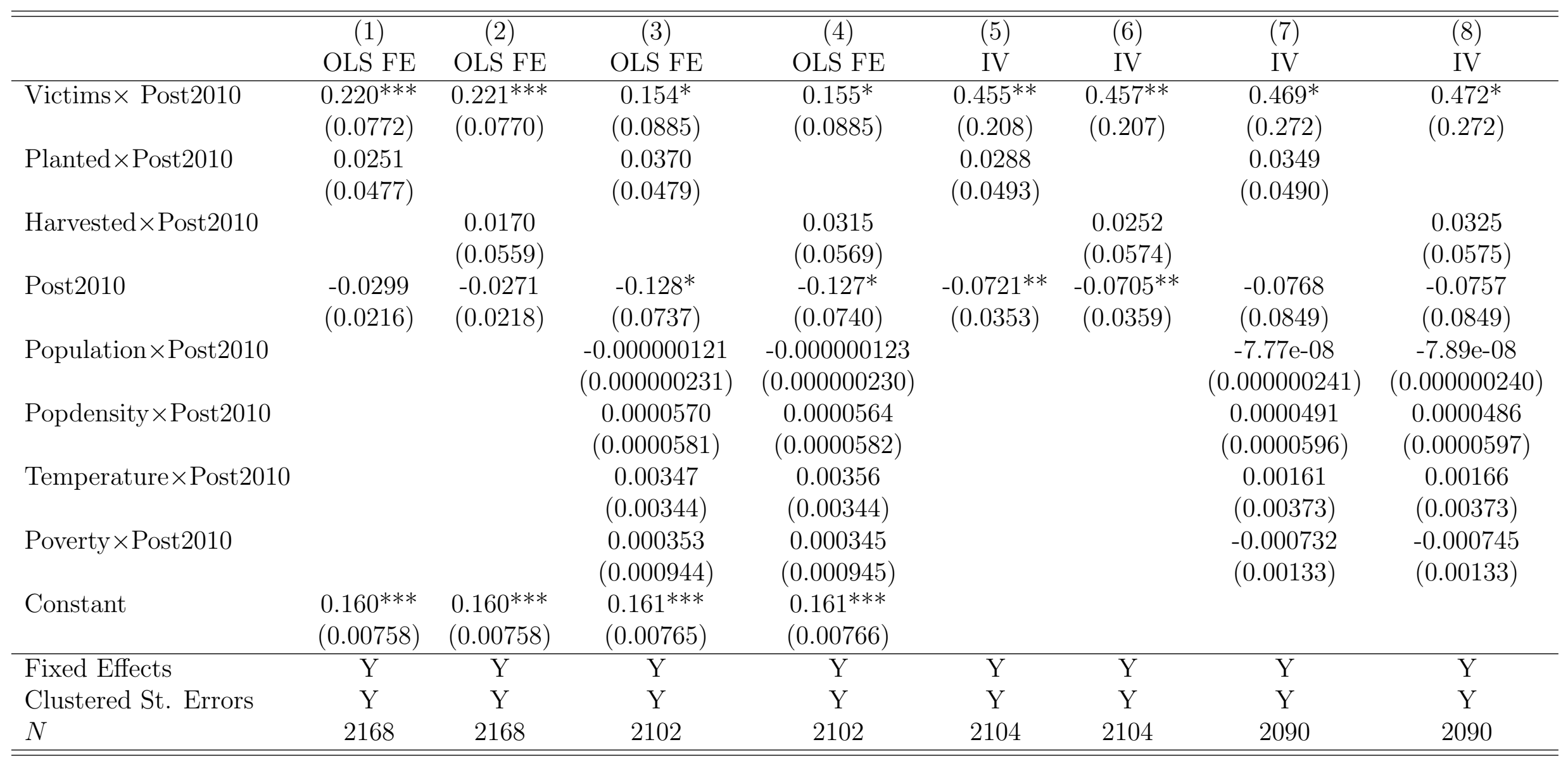

\footnotetext{
Standard errors in parentheses

${ }^{*} p<0.10,{ }^{* *} p<0.05,{ }^{* * *} p<0.01$
} 
An alternative way to account for the impact of disasters on economic production is to control for the plantation of the main agricultural products in Colombia. Floods and landslides might have affected the production of certain commodities, which in turn might have exerted an impact on income and political preferences.

To consider these potential sources of bias, alternative specifications are estimated, controlling for the plantation of Colombia's main agricultural commodites, as reported by the National Administrative Department of Statistics (DANE). Planted areas in hectares per capita in 2007, for coffee, rice, banana, potato, and plantain, are interacted with the Post2010 dummy, in order to test if the effect of disaster victimization on the probability of reelecting the incumbent party is confounded with agricultural shocks. Tables A3 and A4 reveal that the results of the DID estimations reported above (table 2) are robust to the inclusion of these controls. Moreover, as revealed by tables A5 and A6 the results of the IV specification reported on table, are also robust. In any case, the effect of the disaster is to generate a bigger increase in the probability of reelection of the incumbent party in municipalities that were more affected.

\subsection{Mechanism: Disasters, Aid, and Clientelism}

The mechanism proposed in this paper links disasters and clientelism through aid: politicians allocate aid strategically in order to get votes. Figure A3 shows that there is a positive correlation between the amount of food aid allocated by the central government and the number of victims per capita at the municipality level. This strong correlation is corroborated by table A7.

If the mechanism proposed in this paper is correct, it should be the case that in municipalities that received higher levels of aid the probability of reelection should also be higher. Figure A4 illustrates the intuition of the analysis. Once more, I split the sample of municipalities between those that received a high amount of food aid (above the 80th percentile) and those that received a low amount. The incumbent party reelection pattern is depicted in the graph. In places that received high amounts of food aid the proportion of races won by the incumbent party increased from 2007 to 2011. In contrast, this proportion decreased for municipalities that received lower amounts. Therefore, it seems to be the case that food aid increases the probability of reelection for local governments that received it. 
Table A3: Victimization and Reelection: Main Agricultural Products (Without Controls)

\begin{tabular}{lcccccc}
\hline \hline & $(1)$ & $(2)$ & $(3)$ & $(4)$ & $(5)$ & $(6)$ \\
& OLS FE & OLS FE & OLS FE & OLS FE & OLS FE & OLS FE \\
\hline Victims $\times$ Post2010 & $0.225^{* * *}$ & $0.241^{* * *}$ & $0.227^{* * *}$ & $0.217^{* * *}$ & $0.219^{* * *}$ & $0.228^{* * *}$ \\
& $(0.0768)$ & $(0.0806)$ & $(0.0767)$ & $(0.0775)$ & $(0.0771)$ & $(0.0815)$ \\
Coffee $\times$ Post2010 & 0.00766 & & & & & -0.203 \\
& $(0.165)$ & & & & & $(0.217)$ \\
Rice $\times$ Post2010 & & -0.978 & & & & -1.352 \\
Banana $\times$ Post2010 & & $(1.272)$ & & & & $(1.298)$ \\
Potato $\times$ Post2010 & & & -0.856 & & & -0.991 \\
& & & $(0.846)$ & & & $-0.928)$ \\
Plantain $\times$ Post2010 & & & & -0.337 & & -0.332 \\
& & & & $(0.269)$ & & $0.272)$ \\
Post2010 & & & & 0.507 & $0.711^{*}$ \\
& -0.0224 & -0.0221 & -0.0206 & -0.0163 & -0.0321 & -0.0188 \\
Constant & $(0.0204)$ & $(0.0186)$ & $(0.0187)$ & $(0.0194)$ & $(0.0198)$ & $(0.0217)$ \\
& $0.160^{* * *}$ & $0.160^{* * *}$ & $0.160^{* * *}$ & $0.160^{* * *}$ & $0.160^{* * *}$ & $0.160^{* * *}$ \\
\hline Other Controls & $(0.00755)$ & $(0.00755)$ & $(0.00755)$ & $(0.00755)$ & $(0.00754)$ & $(0.00754)$ \\
Fixed Effects & $\mathrm{N}$ & $\mathrm{N}$ & $\mathrm{N}$ & $\mathrm{N}$ & $\mathrm{N}$ & $\mathrm{N}$ \\
Clustered St. Errors & $\mathrm{Y}$ & $\mathrm{Y}$ & $\mathrm{Y}$ & $\mathrm{Y}$ & $\mathrm{Y}$ & $\mathrm{Y}$ \\
$N$ & 2200 & 2200 & 2200 & 2200 & 2200 & 2200 \\
\hline \hline
\end{tabular}

Standard errors in parentheses

${ }^{*} p<0.10,{ }^{* *} p<0.05,{ }^{* * *} p<0.01$

Figure A3: Correlation Between Victims and Food Aid (per Capita Levels)

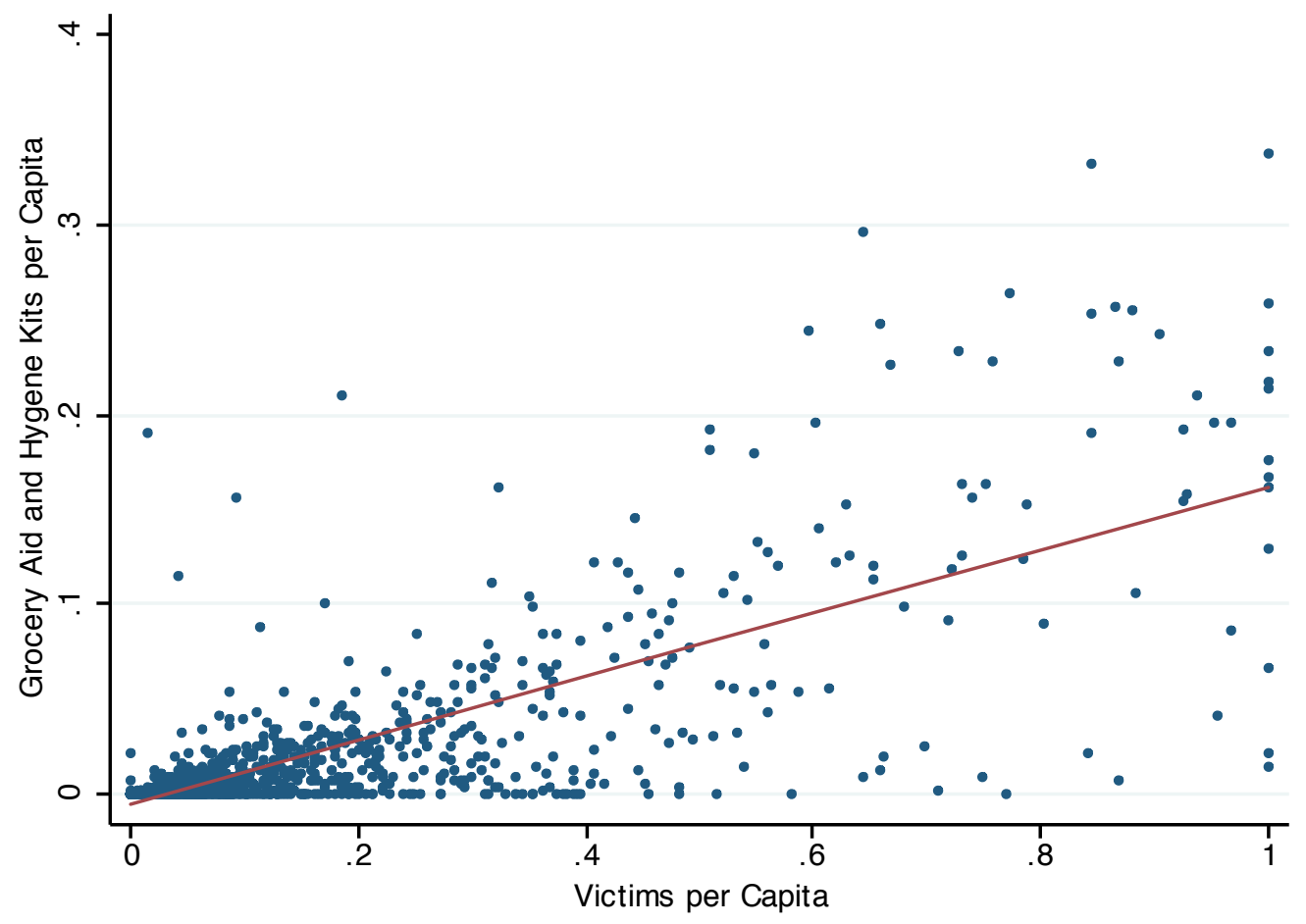


Table A4: Victimization and Reelection: Main Agricultural Products (With Controls)

\begin{tabular}{lcccccc}
\hline \hline & $(1)$ & $(2)$ & $(3)$ & $(4)$ & $(5)$ & $(6)$ \\
& OLS FE & OLS FE & OLS FE & OLS FE & OLS FE & OLS FE \\
\hline Victims $\times$ Post2010 & $0.150^{*}$ & $0.170^{*}$ & $0.154^{*}$ & $0.150^{*}$ & $0.146^{*}$ & $0.172^{*}$ \\
& $(0.0879)$ & $(0.0894)$ & $(0.0881)$ & $(0.0880)$ & $(0.0881)$ & $(0.0896)$ \\
Coffee $\times$ Post2010 & 0.0522 & & & & & -0.167 \\
Rice $\times$ Post2010 & $(0.169)$ & & & & & $(0.223)$ \\
Banana $\times$ Post2010 & & -1.775 & & & & -1.928 \\
& & $(1.393)$ & & & & $(1.417)$ \\
Potato $\times$ Post2010 & & & -0.770 & & & -0.969 \\
& & & $(0.836)$ & & & $-0.929)$ \\
Plantain $\times$ Post2010 & & & & -0.244 & & $(0.300)$ \\
& & & & & 0.545 & $0.728^{*}$ \\
Post2010 & -0.105 & -0.115 & -0.0962 & -0.0745 & -0.105 & -0.0801 \\
& $(0.0744)$ & $(0.0735)$ & $(0.0729)$ & $(0.0793)$ & $(0.0729)$ & $(0.0827)$ \\
Constant & $0.161^{* * *}$ & $0.161^{* * *}$ & $0.161^{* * *}$ & $0.161^{* * *}$ & $0.161^{* * *}$ & $0.161^{* * *}$ \\
& $(0.00762)$ & $(0.00762)$ & $(0.00762)$ & $(0.00762)$ & $(0.00761)$ & $(0.00761)$ \\
\hline Other Controls & $\mathrm{Y}$ & $\mathrm{Y}$ & $\mathrm{Y}$ & $\mathrm{Y}$ & $\mathrm{Y}$ & $\mathrm{Y}$ \\
Fixed Effects & $\mathrm{Y}$ & $\mathrm{Y}$ & $\mathrm{Y}$ & $\mathrm{Y}$ & $\mathrm{Y}$ & $\mathrm{Y}$ \\
Clustered St. Errors & $\mathrm{Y}$ & $\mathrm{Y}$ & $\mathrm{Y}$ & $\mathrm{Y}$ & $\mathrm{Y}$ & $\mathrm{Y}$ \\
$N$ & 2134 & 2134 & 2134 & 2134 & 2134 & 2134 \\
\hline \hline
\end{tabular}

Standard errors in parentheses

${ }^{*} p<0.10,{ }^{* *} p<0.05,{ }^{* * *} p<0.01$

Figure A4: Food Aid and Reelection

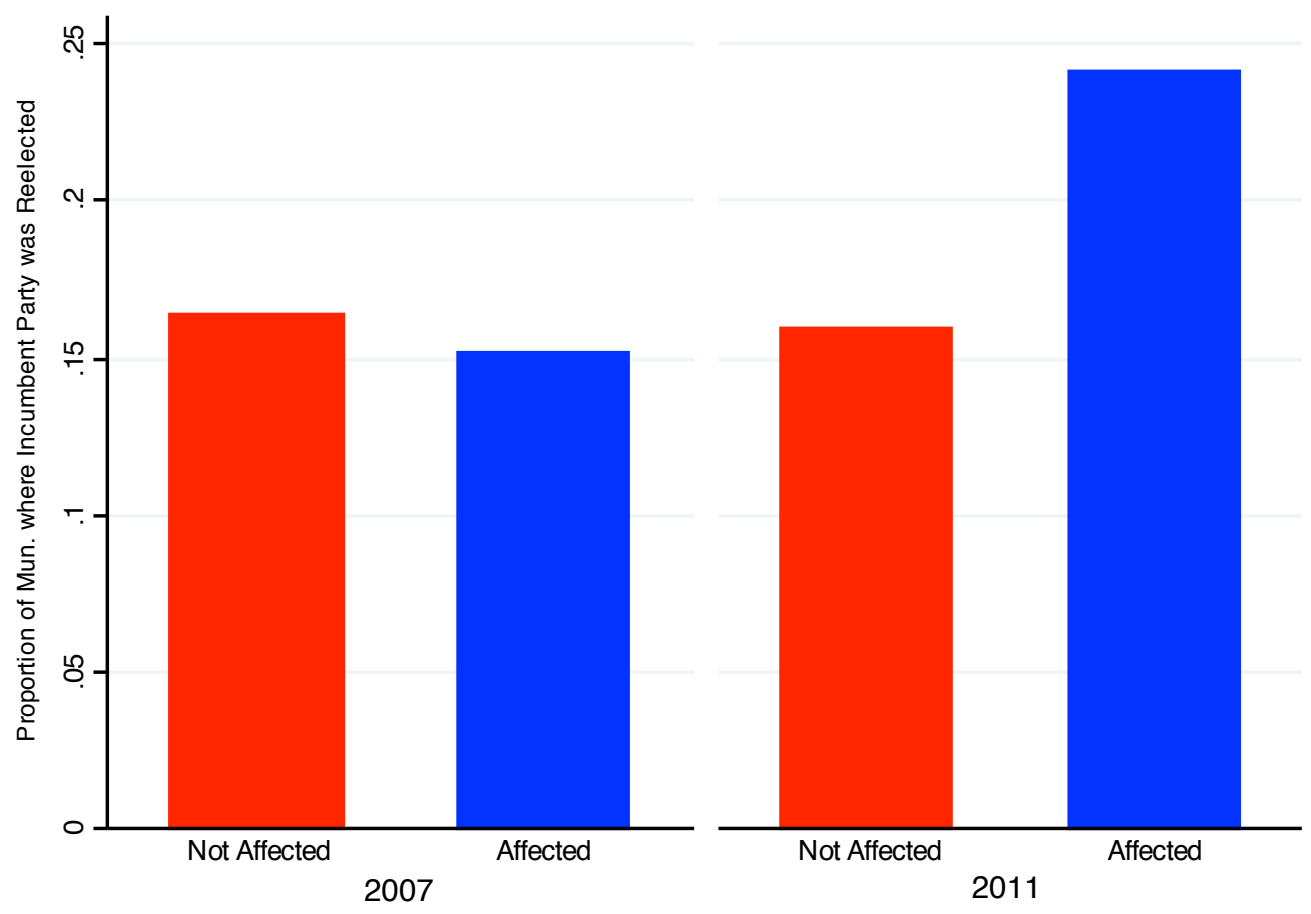


Table A5: Main Agricultural Products: IV Estimation (Without Controls)

\begin{tabular}{lcccccc}
\hline \hline & $(1)$ & $(2)$ & $(3)$ & $(4)$ & $(5)$ & $(6)$ \\
& IV & IV & IV & IV & IV & IV \\
\hline Victims $\times$ Post2010 & $0.456^{* *}$ & $0.445^{* *}$ & $0.444^{* *}$ & $0.440^{* *}$ & $0.467^{* *}$ & $0.431^{* *}$ \\
& $(0.208)$ & $(0.206)$ & $(0.207)$ & $(0.210)$ & $(0.206)$ & $(0.206)$ \\
Coffee $\times$ Post2010 & 0.0490 & & & & & -0.163 \\
& $(0.165)$ & & & & & $(0.218)$ \\
Rice $\times$ Post2010 & & -2.312 & & & & -2.567 \\
& & $(1.728)$ & & & & $(1.736)$ \\
Banana $\times$ Post2010 & & & -0.892 & & & -1.088 \\
& & & $(0.878)$ & & & $(0.974)$ \\
Potato $\times$ Post2010 & & & & -0.236 & & -0.248 \\
& & & & $(0.288)$ & & $(0.287)$ \\
Plantain $\times$ Post2010 & & & & & 0.487 & $0.680^{*}$ \\
& & & & & $(0.351)$ & $(0.400)$ \\
Post2010 & $-0.0646^{*}$ & $-0.0555^{*}$ & $-0.0587^{*}$ & -0.0567 & $-0.0745^{* *}$ & -0.0542 \\
& $(0.0359)$ & $(0.0321)$ & $(0.0343)$ & $(0.0358)$ & $(0.0342)$ & $(0.0341)$ \\
\hline Other Controls & $\mathrm{N}$ & $\mathrm{N}$ & $\mathrm{N}$ & $\mathrm{N}$ & $\mathrm{N}$ & $\mathrm{N}$ \\
Fixed Effects & $\mathrm{Y}$ & $\mathrm{Y}$ & $\mathrm{Y}$ & $\mathrm{Y}$ & $\mathrm{Y}$ & $\mathrm{Y}$ \\
Clustered St. Errors & $\mathrm{Y}$ & $\mathrm{Y}$ & $\mathrm{Y}$ & $\mathrm{Y}$ & $\mathrm{Y}$ & $\mathrm{Y}$ \\
$N$ & 2136 & 2136 & 2136 & 2136 & 2136 & 2136 \\
\hline \hline
\end{tabular}

Standard errors in parentheses

${ }^{*} p<0.10,{ }^{* *} p<0.05,{ }^{* * *} p<0.01$

Table A6: Main Agricultural Products: IV Estimation (With Controls)

\begin{tabular}{lcccccc}
\hline \hline & $(1)$ & $(2)$ & $(3)$ & $(4)$ & $(5)$ & $(6)$ \\
& IV & IV & IV & IV & IV & IV \\
\hline Victims $\times$ Post2010 & $0.455^{*}$ & 0.411 & $0.447^{*}$ & $0.461^{*}$ & $0.483^{*}$ & $0.426^{*}$ \\
& $(0.268)$ & $(0.256)$ & $(0.271)$ & $(0.272)$ & $(0.269)$ & $(0.250)$ \\
Coffee $\times$ Post2010 & 0.0148 & & & & & -0.194 \\
& $(0.171)$ & & & & & $(0.224)$ \\
Rice $\times$ Post2010 & & -2.576 & & & & $-2.788^{*}$ \\
Banana $\times$ Post2010 & & $(1.605)$ & & & & $(1.624)$ \\
& & & -1.017 & & & -1.133 \\
Potato $\times$ Post2010 & & & $(0.919)$ & & & $(0.983)$ \\
& & & & -0.237 & & -0.237 \\
Plantain $\times$ Post2010 & & & & $(0.301)$ & & $(0.305)$ \\
& & & & & 0.474 & $0.702^{*}$ \\
Post2010 & -0.0532 & -0.0859 & -0.0496 & -0.0267 & -0.0518 & -0.0452 \\
& $(0.0859)$ & $(0.0787)$ & $(0.0836)$ & $(0.0892)$ & $(0.0833)$ & $(0.0887)$ \\
\hline Other Controls & $\mathrm{Y}$ & $\mathrm{Y}$ & $\mathrm{Y}$ & $\mathrm{Y}$ & $\mathrm{Y}$ & $\mathrm{Y}$ \\
Fixed Effects & $\mathrm{Y}$ & $\mathrm{Y}$ & $\mathrm{Y}$ & $\mathrm{Y}$ & $\mathrm{Y}$ & $\mathrm{Y}$ \\
Clustered St. Errors & $\mathrm{Y}$ & $\mathrm{Y}$ & $\mathrm{Y}$ & $\mathrm{Y}$ & $\mathrm{Y}$ & $\mathrm{Y}$ \\
$N$ & 2122 & 2122 & 2122 & 2122 & 2122 & 2122 \\
\hline \hline
\end{tabular}

Standard errors in parentheses

${ }^{*} p<0.10,{ }^{* *} p<0.05,{ }^{* * *} p<0.01$ 
Table A7: Victimization and Food Aid: OLS Cross-Sectional Estimates

\begin{tabular}{lcccc}
\hline \hline & $(1)$ & $(2)$ & $(3)$ & $(4)$ \\
& Food Aid & Food Aid & Food Aid & Food Aid \\
\hline Victims & $0.167^{* * *}$ & $0.167^{* * *}$ & $0.165^{* * *}$ & $0.168^{* * *}$ \\
& $(0.00439)$ & $(0.00442)$ & $(0.00459)$ & $(0.00493)$ \\
Population & & $1.21 \mathrm{e}-09$ & $-2.92 \mathrm{e}-09$ & $-4.54 \mathrm{e}-09$ \\
& & $(9.18 \mathrm{e}-09)$ & $(8.66 \mathrm{e}-09)$ & $(8.69 \mathrm{e}-09)$ \\
Popdensity & & 0.0000008 & 0.000001 & 0.0000006 \\
& & $(0.000002)$ & $(0.000002)$ & $(0.000002)$ \\
Temperature & & & $0.0008^{* * *}$ & $0.0009^{* * *}$ \\
& & & $(0.0002)$ & $(0.0002)$ \\
Poverty & & & & $-0.0001^{* *}$ \\
& & & & $(0.00005)$ \\
Constant & $-0.00522^{* * *}$ & $-0.00540^{* * *}$ & $-0.0224^{* * *}$ & $-0.0190^{* * *}$ \\
& $(0.00116)$ & $(0.00121)$ & $(0.00389)$ & $(0.00419)$ \\
\hline$R^{2}$ & 0.5778 & 0.5795 & 0.6003 & 0.5990 \\
$F$ Stat & 1443.93 & 482.78 & 384.42 & 304.49 \\
$N$ & 1057 & 1055 & 1029 & 1025 \\
\hline \hline
\end{tabular}

Standard errors in parentheses

${ }^{*} p<0.10,{ }^{* *} p<0.05,{ }^{* * *} p<0.01$

Figure A3 shows that a similar pattern holds for infrastructure aid, or what we could call, collective spending. There is a positive correlation between the amount of money allocated by the central government and the number of victims. Places more affected received more money.

Table A8 captures this correlation through a series of cross-sectional linear regressions of infrastructure aid on the number of victims (in per capita levels). As expected, the correlation between both variables is positive, and the result is robust to the inclusion of demographic, temperature, and poverty controls. However, compared to the results reported in table A7, the $R$-squared in each case shows that the victims variable explains a higher proportion of the variation in food allocation than infrastructure aid variation.

\subsection{Alternative Mechanisms}

It is possible that incumbents do better in municipalities more affected by the disasters because voters reward politicians who are efficient at ameliorating the negative consequences of the catastrophe. Figure A6 provides descriptive evidence against this assertion. 
Figure A5: Correlation Between Victims and Infrastructure Aid (per Capita Levels)

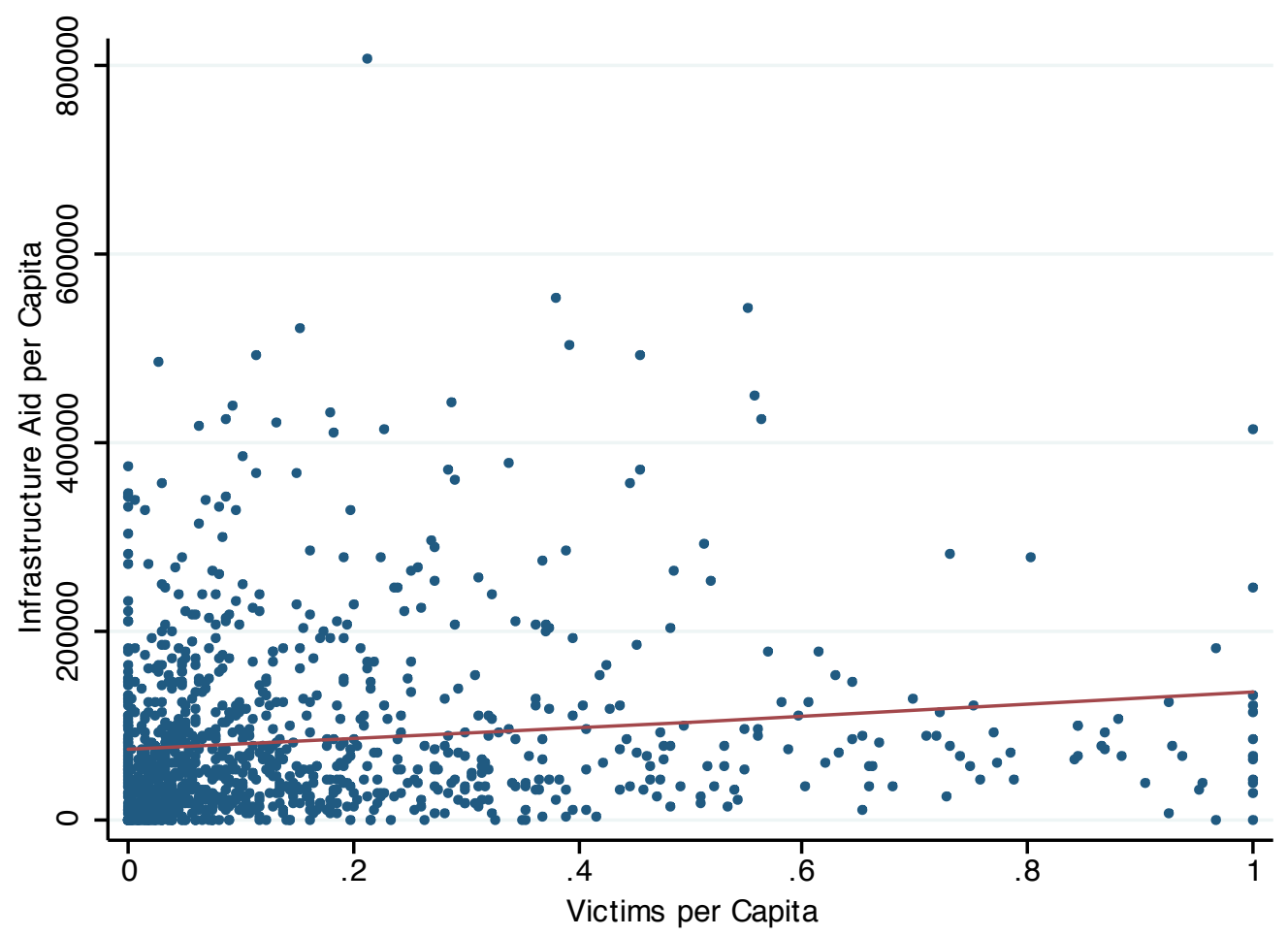

Table A8: Victimization and Infrastructure Aid: OLS Cross-Sectional Estimates

\begin{tabular}{|c|c|c|c|c|}
\hline & $\begin{array}{c}(1) \\
\text { Infrastructure }\end{array}$ & $\begin{array}{c}(2) \\
\text { Infrastructure }\end{array}$ & $\begin{array}{c}(3) \\
\text { Infrastructure }\end{array}$ & $\begin{array}{c}(4) \\
\text { Infrastructure }\end{array}$ \\
\hline Victims & $\begin{array}{c}60899.8^{* * *} \\
(13322.2)\end{array}$ & $\begin{array}{c}55921.1^{* * *} \\
(13293.2)\end{array}$ & $\begin{array}{c}98432.1^{* * *} \\
(14046.0)\end{array}$ & $\begin{array}{c}96017.4^{* * *} \\
(14930.2)\end{array}$ \\
\hline Population & & $\begin{array}{c}-0.0264^{* *} \\
(0.0125)\end{array}$ & $\begin{array}{c}-0.0256^{* *} \\
(0.0120)\end{array}$ & $\begin{array}{c}-0.0253^{* *} \\
(0.0120)\end{array}$ \\
\hline Popdensity & & $\begin{array}{c}-11.44^{* *} \\
(4.510)\end{array}$ & $\begin{array}{c}-11.40^{* * *} \\
(4.343)\end{array}$ & $\begin{array}{c}-10.91^{* *} \\
(4.446)\end{array}$ \\
\hline Temperature & & & $\begin{array}{c}-5614.2^{* * *} \\
(556.2)\end{array}$ & $\begin{array}{c}-5711.4^{* * * *} \\
(583.6)\end{array}$ \\
\hline Poverty & & & & $\begin{array}{c}90.81 \\
(162.0)\end{array}$ \\
\hline Constant & $\begin{array}{c}72608.0^{* * *} \\
(3447.6)\end{array}$ & $\begin{array}{c}76253.0^{* * *} \\
(3526.9)\end{array}$ & $\begin{array}{c}191450.3^{* * *} \\
(11973.2)\end{array}$ & $\begin{array}{c}189028.2^{* * *} \\
(12824.7)\end{array}$ \\
\hline$R^{2}$ & 0.0187 & 0.0354 & 0.1214 & 0.1215 \\
\hline$F$ Stat & 20.90 & 13.40 & 36.87 & 29.34 \\
\hline$N$ & 1100 & 1098 & 1072 & 1067 \\
\hline
\end{tabular}

Standard errors in parentheses

${ }^{*} p<0.10,{ }^{* *} p<0.05,{ }^{* * *} p<0.01$ 
Figure A6: Reelection in 2011 and Delayed Projects

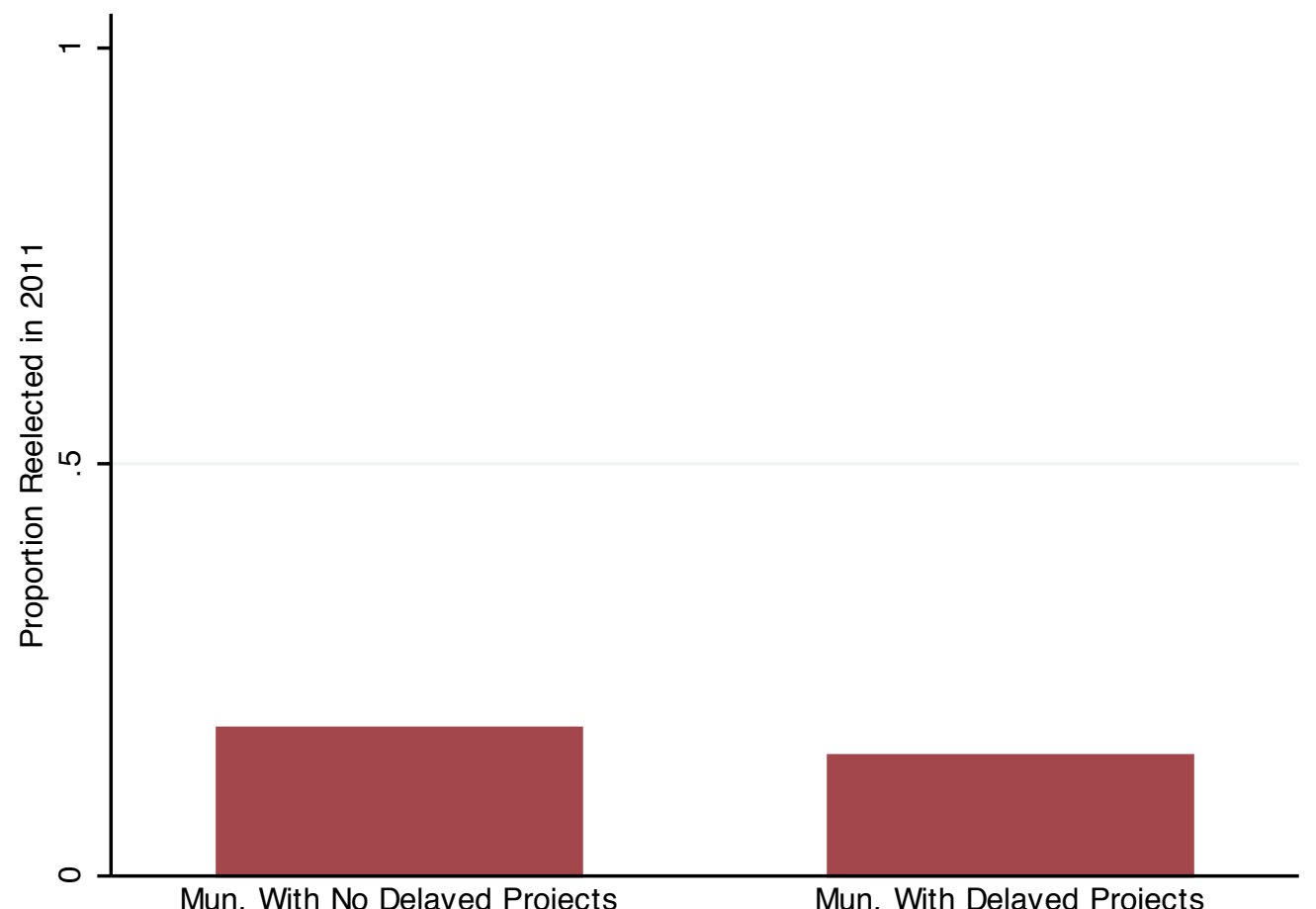

The graph shows that in municipalities with no delayed projects -according to the Attorney's office- the proportion of elections won by the incumbent party in 2011 is very similar to the analogous proportion in places that exhibit delays. A test of difference in means fails to reject the null hypothesis that both proportions are the same (results not shown). Columns 1-5 in table 5 of the paper present stronger support for this conclusion.

A second alternative mechanism is that the disaster changed the levels of political engagement of victims, making them support more incumbents. If this assertion is true, turnout should change more in places more affected by the disasters. However, figure A7 and columns 5-8 in table 5 provide evidence against this alternative explanation. 
Figure A7: Correlation Between Victims per Capita and Voter Turnout

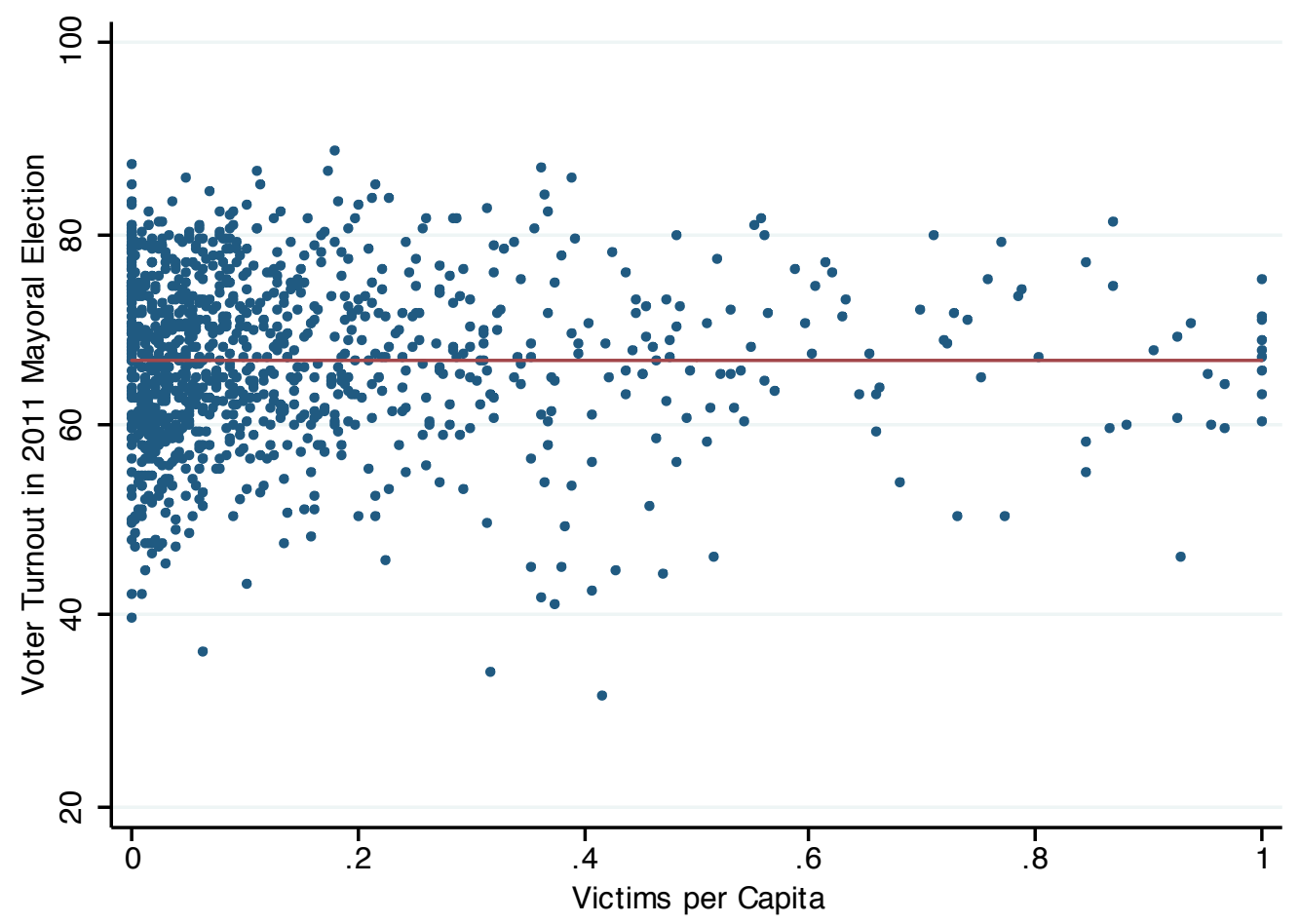

